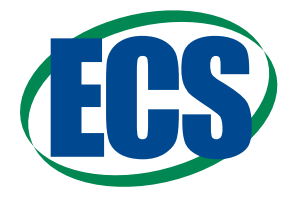

JeS Focus Issue on Processes at the Semiconductor-Solution Interface

\title{
Review-Copper Oxide-Based Ternary and Quaternary Oxides: Where Solid-State Chemistry Meets Photoelectrochemistry
}

\author{
Krishnan Rajeshwar, @1,*,z Mohammad Kabir Hossain, 1,** Robin T. Macaluso, ${ }^{1}$ \\ Csaba Janáky, ${ }^{2,3}$ Andras Varga, ${ }^{2,3}$ and Pawel J. Kulesza ${ }^{4, * * *}$ \\ ${ }^{I}$ Department of Chemistry \& Biochemistry, The University of Texas at Arlington, Arlington, Texas 76109-0065, USA \\ ${ }^{2}$ MTA-SZTE, Lendület Photoelectrochemistry Research Group, Szeged H-6720, Hungary \\ ${ }^{3}$ Department of Physical Chemistry and Materials Science, University of Szeged, Szeged H-6720, Hungary \\ ${ }^{4}$ Faculty of Chemistry, University of Warsaw, PL-02-093 Warsaw, Poland
}

This review article addresses areas where solid-state chemistry concepts can contribute to the on-going search for a "magic bullet" inorganic semiconductor that can efficiently split water or reduce $\mathrm{CO}_{2}$. First, a methodology to visualize complex ternary oxide combinations is outlined using 31 examples based on copper in both +1 and +2 oxidation states. Then the synthetic aspects are reviewed followed by a discussion of the structural characteristics. The optoelectronic aspects are considered next, culminating the review with the state-of-the-art in the practical applicability of these materials in solar fuels photogeneration and environmental (e.g., azo dye) remediation.

(c) The Author(s) 2018. Published by ECS. This is an open access article distributed under the terms of the Creative Commons Attribution 4.0 License (CC BY, http://creativecommons.org/licenses/by/4.0/), which permits unrestricted reuse of the work in any medium, provided the original work is properly cited. [DOI: 10.1149/2.0271804jes]

(cc) BY

Manuscript submitted January 15, 2018; revised manuscript received March 6, 2018. Published March 24, 2018. This paper is part of the JES Focus Issue on Processes at the Semiconductor-Solution Interface.

This review article addresses the nexus between two seemingly disparate disciplines, namely solid-state chemistry (SSC) and photoelectrochemistry (PEC) using copper-based complex (ternary and quaternary) oxides as a discussion framework. The two disciplines, SSC and PEC, have more or less developed in a parallel fashion since their halcyon days in the mid-1970s. Both SSC and PEC shared an interest in similar materials (mainly oxides and chalcogenides) but for rather different applications. While SSC has focused mainly on magnetic or electronically and ionically conductive solid materials, and eventually evolving to superconducting (so-called high $\mathrm{T}_{\mathrm{c}}$ ) materials, PEC has dealt mainly with inorganic semiconductors. However, and interestingly enough, the two disciplines have coalesced in the area of energy conversion. The past couple decades have thus witnessed remarkable advances in the development of solid-state materials for Li-ion batteries, thermoelectric conversion, photovoltaic solar cells, and solid-oxide fuel cells. Even high $\mathrm{T}_{\mathrm{c}}$-superconductivity studies have translated to niche applications in practical technologies. However, in spite of a comparably early history of study, solar fuels (e.g., water splitting, $\mathrm{CO}_{2}$ reduction, $\mathrm{N}_{2}$ reduction) have not seen the light of day in terms of commercialization.

One may well argue that we lack a "magic bullet" inorganic semiconductor that can split water or reduce $\mathrm{CO}_{2}$ in a stable, sustainable, and efficient manner because the connection between SSC and PEC has only occurred in fits and starts. With the entry of (a veritable melting pot of) scientists from a wide variety of technical backgrounds (e.g., colloid chemistry, ultrafast spectroscopy, solid-state physics, electrochemistry, etc.) into the PEC field, it was only natural that the emphasis on solid state chemistry has been somewhat diluted. For example, while the early history of PEC is liberally sprinkled with studies from solid-state research groups (see Refs. 1-4 as random examples), instances in the post $1990 \mathrm{~s}$ where SSC concepts have been rationally and deliberately applied, are sporadic, ${ }^{5,6}$ as further discussed below.

\section{Scope of Review and Literature Precedence}

This review refocuses the key role that solid-state chemistry can play in the continuing search for an inorganic semiconductor (or

*Electrochemical Society Fellow.

**Electrochemical Society Student Member

***Electrochemical Society Member

${ }^{\mathrm{z}}$ E-mail: rajeshwar@uta.edu a combination of semiconductors) for solar fuels photogeneration. First, means of visualizing complex oxide chemical compositions are introduced via suitable diagrams. Next, the synthetic aspects are considered followed by a review of the structural aspects of copper oxide-based ternary and quaternary oxides starting with the parent oxides, copper(I) oxide and copper(II) oxide $\left(\mathrm{Cu}_{2} \mathrm{O}\right.$ and $\left.\mathrm{CuO}\right)$. The optoelectronic attributes are discussed in turn, culminating in an examination of the extent to which these new materials have met the needs for applicability in the solar fuels and environmental remediation arenas.

We are not aware of a similar, overarching review on this topic although copper(I)-based $p$-type oxides were recently reviewed for photoelectrochemical and photovoltaic solar energy conversion applications. ${ }^{6}$ Tantalum- and niobium-based ternary oxides were discussed in this particular article, as were four copper(I) delafossites and two $\mathrm{Cu}-\mathrm{V}-\mathrm{O}$ oxides $\left(\mathrm{Cu}_{3} \mathrm{VO}_{4}\right.$ and $\left.\mathrm{Cu}_{2} \mathrm{~V}_{3} \mathrm{O}_{8}\right){ }^{6}$ Areas where the present article overlaps with this precedent review are identified later. The synthetic aspects of ternary metal oxide nanostructures have been reviewed ${ }^{7}$ as were their applications in supercapacitors. ${ }^{8}$ While not focusing per se on solar fuels generation, three recent articles ${ }^{9-11}$ may be cited that share a similar objective to the present review: namely, targeted materials development for a specific application. Thus, we note a recent article that discusses how simple chemical concepts can be turned into viable strategies for thermoelectric materials development. ${ }^{9}$

Another article ${ }^{10}$ focuses on the accuracy of density functional theory in predicting the formation energetics of ternary oxides from their binary oxide counterparts. Finally, ab initio global structural prediction, and specifically the minima hopping method, was used to study 183 different compositions of the form, $\mathrm{MXO}_{2}$, where $\mathrm{M}=\mathrm{Cu}, \mathrm{Ag}$, or Au (coinage metal), and $\mathrm{X}$ is an element in the Periodic Table. ${ }^{11}$ The application target in this particular study was $p$-type transparent conducting oxide (TCO) development. ${ }^{11}$ While the materials' application focus in the present discussion is mostly on solar water splitting, closely allied technology aspects related to photoelectrochemical $\mathrm{CO}_{2}$ reduction and heterogeneous photocatalytic environmental remediation are also peripherally addressed, for the sake of completeness. It is worth noting that the photocatalysis application has seen the light of day, in terms of commercial realization, sooner than the other applications.

Tables Ia and Ib summarize the oxide candidates considered in the present review article; the two compilations relate to compounds based on copper in the +1 and +2 oxidation states respectively. 


\section{Table I. Copper oxide-based ternary oxides considered in this review. a) Copper(I) oxide-based. b) Copper(II) oxide-based.}

\begin{tabular}{|c|c|c|c|c|c|}
\hline No. & Ternary Oxide & A oxide & B oxide & A oxide: B oxide & $\operatorname{Ref}(s)$ \\
\hline \multicolumn{6}{|c|}{ a) Copper(I) oxide-based } \\
\hline 1 & $\mathrm{CuAlO}_{2}$ & $\mathrm{Cu}_{2} \mathrm{O}$ & $\mathrm{Al}_{2} \mathrm{O}_{3}$ & 1: 1 & $12-15$ \\
\hline 2 & $\mathrm{CuCrO}_{2}$ & & $\mathrm{Cr}_{2} \mathrm{O}_{3}$ & 1: 1 & 16,17 \\
\hline 3 & $\mathrm{CuFeO}_{2}$ & & $\mathrm{Fe}_{2} \mathrm{O}_{3}$ & 1: 1 & $5,18-21$ \\
\hline 4 & $\alpha-\mathrm{CuGaO}_{2}$ & & $\mathrm{Ga}_{2} \mathrm{O}_{3}$ & 1: 1 & $22-26$ \\
\hline 5 & $\beta-\mathrm{CuGaO}_{2}$ & & $\mathrm{Ga}_{2} \mathrm{O}_{3}$ & 1: 1 & 27,28 \\
\hline 6 & $\mathrm{CuNbO}_{3}$ & & $\mathrm{Nb}_{2} \mathrm{O}_{5}$ & 1: 1 & 29,30 \\
\hline 7 & $\mathrm{CuNb}_{3} \mathrm{O}_{8}$ & & $\mathrm{Nb}_{2} \mathrm{O}_{5}$ & $1: 3$ & 31,32 \\
\hline 8 & $\mathrm{Cu}_{2} \mathrm{Nb}_{8} \mathrm{O}_{21}$ & & $\mathrm{Nb}_{2} \mathrm{O}_{5}$ & $1: 4$ & 33 \\
\hline 9 & $\mathrm{CuRhO}_{2}$ & & $\mathrm{Rh}_{2} \mathrm{O}_{3}$ & 1: 1 & 34 \\
\hline 10 & $\alpha-\mathrm{Cu}_{2} \mathrm{Ta}_{4} \mathrm{O}_{11}$ & & $\mathrm{Ta}_{2} \mathrm{O}_{5}$ & $1: 2$ & 35 \\
\hline 11 & $\beta-\mathrm{Cu}_{2} \mathrm{Ta}_{4} \mathrm{O}_{11}$ & & $\mathrm{Ta}_{2} \mathrm{O}_{5}$ & 1: 2 & 36 \\
\hline 12 & $\mathrm{Cu}_{3} \mathrm{Ta}_{7} \mathrm{O}_{19}$ & & $\mathrm{Ta}_{2} \mathrm{O}_{5}$ & $3: 7$ & 37,38 \\
\hline 13 & $\mathrm{Cu}_{5} \mathrm{Ta}_{11} \mathrm{O}_{30}$ & & $\mathrm{Ta}_{2} \mathrm{O}_{5}$ & 5: 11 & 37,39 \\
\hline 14 & $\mathrm{Cu}_{3} \mathrm{VO}_{4}$ & & $\mathrm{~V}_{2} \mathrm{O}_{5}$ & $3: 1$ & 40 \\
\hline \multicolumn{6}{|c|}{ b) Copper(II) oxide-based } \\
\hline 1 & $\mathrm{CuAl}_{2} \mathrm{O}_{4}$ & $\mathrm{CuO}$ & $\mathrm{Al}_{2} \mathrm{O}_{3}$ & 1: 1 & $41-44$ \\
\hline 2 & $\mathrm{CuBi}_{2} \mathrm{O}_{4}$ & & $\mathrm{Bi}_{2} \mathrm{O}_{3}$ & 1: 1 & $45-56$ \\
\hline 3 & $\mathrm{CuCO}_{2} \mathrm{O}_{4}$ & & $\mathrm{Co}_{2} \mathrm{O}_{3}$ & 1: 1 & $44,57-59$ \\
\hline 4 & $\mathrm{CuCr}_{2} \mathrm{O}_{4}$ & & $\mathrm{Cr}_{2} \mathrm{O}_{3}$ & 1: 1 & $44,60-66$ \\
\hline 5 & $\mathrm{CuFe}_{2} \mathrm{O}_{4}$ & & $\mathrm{Fe}_{2} \mathrm{O}_{3}$ & 1: 1 & $44,67-69$ \\
\hline 6 & $\mathrm{CuGa}_{2} \mathrm{O}_{4}$ & & $\mathrm{Ga}_{2} \mathrm{O}_{3}$ & $1: 1$ & 70 \\
\hline 7 & $\mathrm{CuMn}_{2} \mathrm{O}_{4}$ & & $\mathrm{Mn}_{2} \mathrm{O}_{3}$ & 1: 1 & 44,71 \\
\hline 8 & $\mathrm{CuMoO}_{4}$ & & $\mathrm{MoO}_{3}$ & 1: 1 & 72,73 \\
\hline 9 & $\mathrm{CuNb}_{2} \mathrm{O}_{6}$ & & $\mathrm{Nb}_{2} \mathrm{O}_{5}$ & 1: 1 & 74 \\
\hline 10 & $\mathrm{Cu}_{3} \mathrm{Nb}_{2} \mathrm{O}_{8}$ & & $\mathrm{Nb}_{2} \mathrm{O}_{5}$ & 3: 1 & 75 \\
\hline 11 & $\mathrm{CuV}_{2} \mathrm{O}_{6}$ & & $\mathrm{~V}_{2} \mathrm{O}_{5}$ & $1: 1$ & $76-78$ \\
\hline 12 & $\alpha-\mathrm{Cu}_{2} \mathrm{~V}_{2} \mathrm{O}_{7}$ & & $\mathrm{~V}_{2} \mathrm{O}_{5}$ & $2: 1$ & 79 \\
\hline 13 & $\beta-\mathrm{Cu}_{2} \mathrm{~V}_{2} \mathrm{O}_{7}$ & & $\mathrm{~V}_{2} \mathrm{O}_{5}$ & $2: 1$ & $76,77,79$ \\
\hline 14 & $\beta-\mathrm{Cu}_{3} \mathrm{~V}_{2} \mathrm{O}_{8}$ & & $\mathrm{~V}_{2} \mathrm{O}_{5}$ & $3: 1$ & $80-83$ \\
\hline 15 & $\gamma-\mathrm{Cu}_{3} \mathrm{~V}_{2} \mathrm{O}_{8}$ & & $\mathrm{~V}_{2} \mathrm{O}_{5}$ & 3: 1 & 79,84 \\
\hline 16 & $\mathrm{Cu}_{11} \mathrm{~V}_{6} \mathrm{O}_{26}$ & & $\mathrm{~V}_{2} \mathrm{O}_{5}$ & $11: 3$ & 79,85 \\
\hline 17 & $\mathrm{CuWO}_{4}$ & & $\mathrm{WO}_{3}$ & $1: 1$ & $86-94$ \\
\hline
\end{tabular}

Figures 1a and 1b illustrate the materials' scope from a Periodic Table perspective.

\section{Visualizing Ternary and Quaternary Oxide Compositions and Their Relationship to the Binary Oxide Components}

In this paper, $\mathrm{A}, \mathrm{B}$, and $\mathrm{C}$ represent metal cations in a ternary or quaternary oxide compound. Of course, for the present discussion, $\mathrm{A}=\mathrm{Cu}$ in all the cases. At first glance, the various oxide compositions in Tables Ia and Ib appear to be complicated in terms of the combinations of formula subscripts, especially in the $\mathrm{Cu}-\mathrm{Nb}-\mathrm{O}, \mathrm{Cu}-\mathrm{Ta}-\mathrm{O}$, and $\mathrm{Cu}-\mathrm{V}-\mathrm{O}$ cases. However, a simple way to visualize these is to break up each ternary compound into a combination of the component binaries. Thus the two binaries are shown in columns 3 and 4 of Tables Ia and $\mathrm{Ib}$ and their combining ratios is shown in column 5 in each case. Thus the vast majority of the compounds considered are rather simple 1:1 molar combinations, although combinations such as 11:3 are observed in the $\mathrm{Cu}-\mathrm{V}-\mathrm{O}$ systems. Polymorphs of the same compound are also observed in many cases (designated in Tables Ia and Ib by $\alpha, \beta$, etc.) and they will be further considered in the section below on structural aspects.

A final point to note is that the prescribed visualization of ternary compounds as combinations of corresponding binaries, is by no means, unique to oxides. This approach works equally well for nonoxides, e.g., chalcogenides, phosphides, arsenides etc. By extrapolation, quaternary compounds may be visualized as derived from the component binaries in the same manner. Thus, the quaternary compound, $\mathrm{AgBiW}_{2} \mathrm{O}_{8}$, studied by one of us recently, ${ }^{95}$ is really a $1: 1: 4$ combination of the three component oxides, namely, $\mathrm{Ag}_{2} \mathrm{O}, \mathrm{Bi}_{2} \mathrm{O}_{3}$, and $\mathrm{WO}_{3}$. Certainly, this is not readily apparent from the above formula! Other $\mathrm{Cu}$-based quaternary compounds are considered below.
Phase diagrams can also represent thermodynamically stable ternary and quaternary compounds based on their simpler components; this is depicted in Figure 2. The generic ternary phase diagram is shown in Figure $2 \mathrm{a}$ and a specific $\mathrm{Cu}-\mathrm{Bi}-\mathrm{V}-\mathrm{O}$ system is considered in Figure 2b. Consider Figure 2a first. Each corner of the (equilateral) triangle represents $100 \%$ of one component (i.e., a binary compound). Points along each edge of the equilateral triangle represent a combination of two binaries on either end of the triangle. Any point on the edge must follow the lever rule; for example, the mid-point constitutes the $1: 1$ ternary compound, and $\mathrm{AB}_{2} \mathrm{O}_{\mathrm{x}}$ is represented as a point that is located $1 / 3$ of the length toward the corner labeled "A-oxide" and $2 / 3$ of the length toward the corner labeled "B-oxide." For example, a point in the middle of the triangle represents an oxide with the chemical formula, $\mathrm{ABCO}_{\mathrm{x}}$, where one expects $33.3 \%$ each of the A-oxide, $\mathrm{B}$-oxide and $\mathrm{C}$-oxide. The convex-hull formalism, ${ }^{10}$ commonly used for thermodynamic predictions, logically derives from similar ideas.

$\mathrm{The} \mathrm{Cu}-\mathrm{V}-\mathrm{O}$ phase space is particularly rich and the four known compounds (Table I) are shown in Figure 2b. The 1:1 compound between $\mathrm{Bi}_{2} \mathrm{O}_{3}$ and $\mathrm{V}_{2} \mathrm{O}_{5}$, positioned at the mid-point on the bottom horizontal edge in Figure $2 \mathrm{~b}$, is the well-studied $\mathrm{BiVO}_{4}$. While not directly relevant for this review on $\mathrm{Cu}$-based oxides, this particular compound is only shown in this diagram because it is a "champion" ternary oxide in terms of performance in solar water splitting. ${ }^{96}$

The $\mathrm{CuO}-\mathrm{V}_{2} \mathrm{O}_{5}$ edge shows four stable ternary compounds that lie on the CuO-rich side of the edge, while the $\mathrm{Bi}_{2} \mathrm{O}_{3}-\mathrm{CuO}$ edge reveals one compound, $\mathrm{CuBi}_{2} \mathrm{O}_{4}$, with a 1:1 molar ratio of $\mathrm{Bi}_{2} \mathrm{O}_{3}$ and $\mathrm{CuO}$. The interior of the triangle in Figure 2 represents the quaternary phase space and one specific $\mathrm{Cu}-\mathrm{Bi}-\mathrm{V}-\mathrm{O}$ compound (the $4: 1: 1$ ratio of $\mathrm{CuO}-\mathrm{Bi}_{2} \mathrm{O}_{3}-\mathrm{V}_{2} \mathrm{O}_{5}$ ) is depicted in Figure $2 \mathrm{~b}$. Compositions beyond the quaternary case will necessitate the use of 3 -D objects for visualization and their rarity puts them beyond the scope of the present discussion.

A final way to consider ternary compositions is to consider them as comprising of ionic fragments of the A cation (i.e., $\mathrm{Cu}^{+}$or $\mathrm{Cu}^{2+}$ ) and the $\mathrm{BO}$ cluster. Indeed the compound name, in many cases, is derived by this underlying idea. To illustrate, $\mathrm{CuBi}_{2} \mathrm{O}_{4}$ or "copper bismuthate" (Table Ib), may be considered to be composed of $\mathrm{Cu}^{2+}$ and $\mathrm{Bi}_{2} \mathrm{O}_{4}{ }^{2-}$ fragments. Similarly, entries \#4 and \#5 in Table $\mathrm{Ib}$ would read as "copper chromate" and "copper ferrate" respectively. There are other also more well-known such examples amongst non- $\mathrm{Cu}$ systems, e.g., bismuth titanates etc. Nonetheless, we favor the visualization based on component oxides instead, especially because the "ionic approach" is difficult to apply to quaternary cases and beyond.

\section{Synthetic Aspects}

As may be expected, a wide range of synthetic methodologies have been deployed for the preparation of ternary oxides based on $\mathrm{Cu}(\mathrm{I})$ and $\mathrm{Cu}$ (II). Figure 3 captures the distribution of a random sampling of these methods in the literature focusing only PEC or photocatalysis applications. Interestingly, ceramic preparation routes account for a significant number of instances in these studies. This trend is entirely in line with the theme of this review on the close relationship between solid-state chemistry and PEC. Worthy also of note is the fact that the "catch-all" (Others) category is the dominant category of methods in the $\mathrm{Cu}$ (II) case. This category includes variant techniques such as ion exchange, solution combustion synthesis, spin-coating, spraypyrolysis, or metal-organic decomposition.

Given that the set of materials attributes needed for a given technological application (e.g., solar water splitting) is rather well understood, ${ }^{97}$ it would have been ideal if a given synthesis set of conditions could be tailored a priori to yield the material with precisely those attributes. Unfortunately, this is not the case given the present state-of-the-art. The targeted attributes may even be contradictory. For example, solar energy conversion applications dictate the use of very large active material area to compensate for the diluteness of the incoming energy source (i.e., sunlight), unless of course concentrator strategies are employed. On the other hand, when nanoparticles of the active material are used, larger crystallite sizes (approaching single crystal behavior!) must be sought to minimize the role of defects and optimize carrier collection. 
(a)
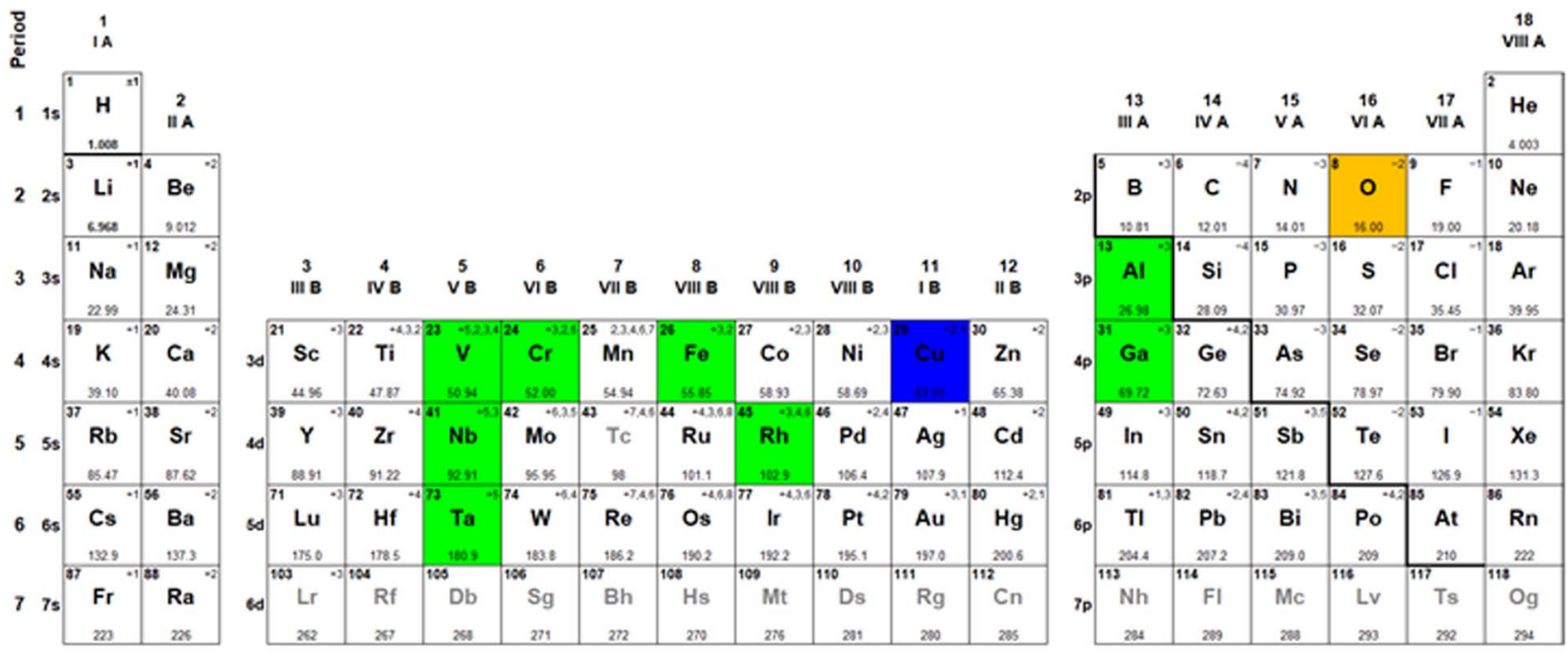

(b)
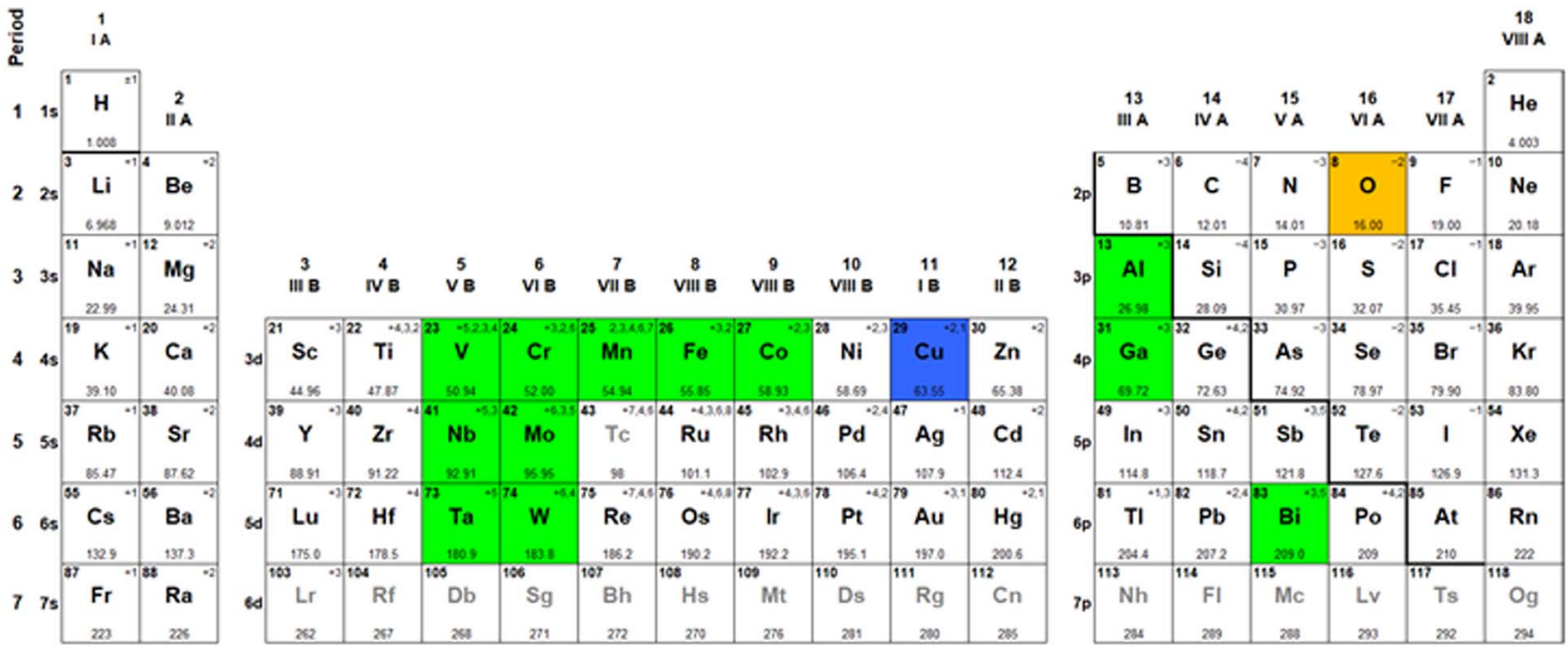

Figure 1. The ternary compounds based on $\mathrm{Cu}(\mathrm{I})$ (a) and $\mathrm{Cu}(\mathrm{II})$ (b) considered in this study and their component elements with respect to the Periodic Table (see also Tables Ia and Ib). As in the crystal structures below, the elements are color-coded, blue being the A cation $(\mathrm{Cu})$ while green is the B cation in the ternary oxide compound.

(a)

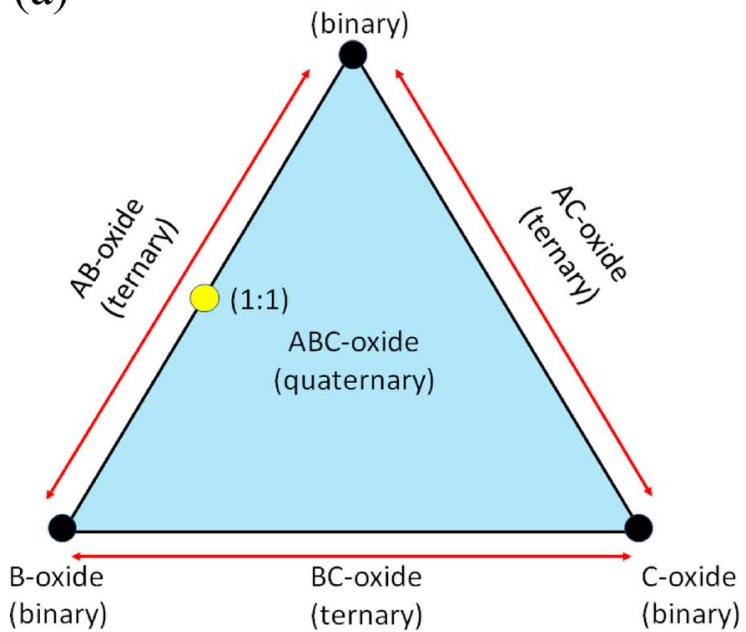

(b)

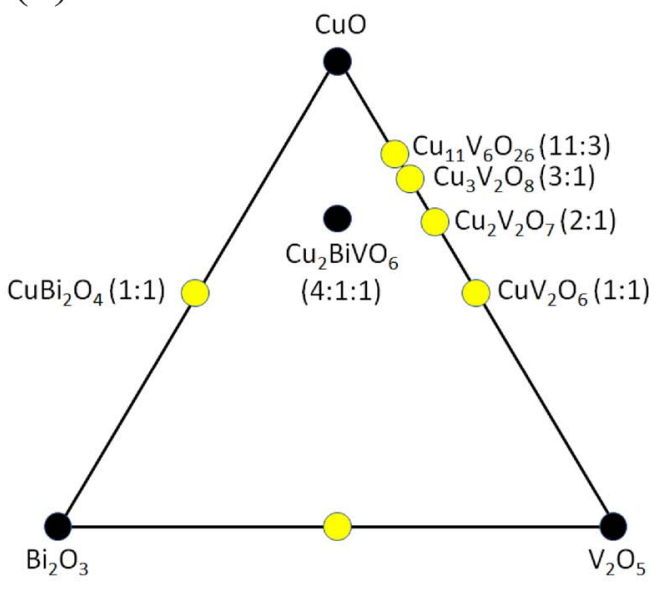

Figure 2. Graphical visualization of ternary and quaternary oxides, for the generic (a) and $\mathrm{Bi}_{2} \mathrm{O}_{3}-\mathrm{CuO}-\mathrm{V}_{2} \mathrm{O}_{5}$ (b) cases. 
(a)

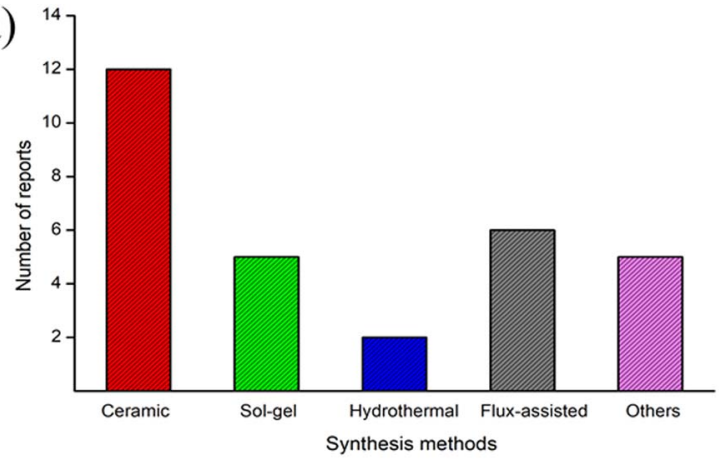

(b)

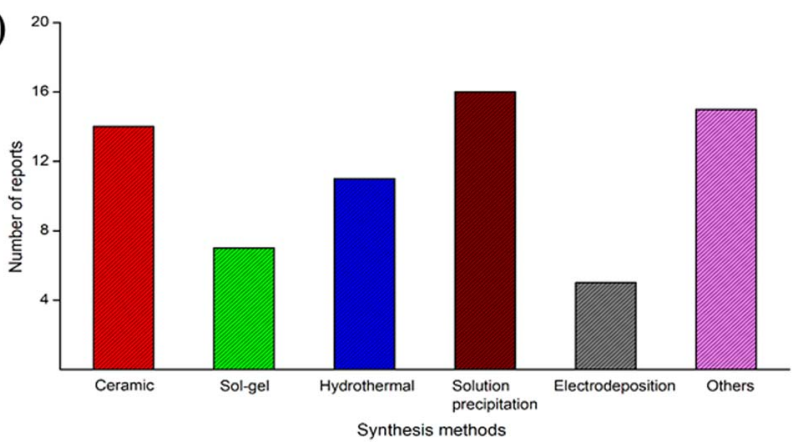

Figure 3. A sampling of the literature on PEC and photocatalysis for the examples of the choice of synthesis approaches for $\mathrm{Cu}(\mathrm{I})$ (a) and $\mathrm{Cu}$ (II) (b) compounds respectively. Refer also to text.

It is clear that in cases where an energy-harvesting material is to be synthesized, the energy investment for the synthesis itself, must be minimized such that the energy payback time is shortened. Solid-state (i.e., ceramic) synthesis routes are handicapped in this regard because they involve rather high temperatures. On the other hand, techniques such as solution combustion synthesis $(\mathrm{SCS})^{55,94}$ are attractive because the thermal energy required for the synthesis is contained within the heat of combustion of the fuel:oxidizer precursor mixture. Another important advantage of SCS is the versatility it offers for tuning the range of composition of the end product simply by varying the precursor ratio. Thus, an entire range of oxide compositions from neat $\mathrm{CuO}$ on the one side to the $1: 1$ ternary, $\mathrm{CuBi}_{2} \mathrm{O}_{4}$, and to $\mathrm{Bi}_{2} \mathrm{O}_{3}$ on the other, could be generated using SCS. ${ }^{55}$ Nanocomposites containing $\mathrm{CuO}$ and $\mathrm{CuBi}_{2} \mathrm{O}_{4}$ nanoparticles in electronic contact or the $\mathrm{Bi}_{2} \mathrm{O}_{3} / \mathrm{CuBi}_{2} \mathrm{O}_{4}$ material could also be synthesized. ${ }^{55}$ Even more significantly, SCS has also afforded the scope for preparing doped oxides or solid solutions as elaborated later in this review.

Materials discovery in its current state of evolution has to rely on either tedious trial-and error methodologies or more efficiently, the combinatorial variant. In this regard, synthesis methods that are time-efficient (such as SCS) hold a significant advantage over prolonged techniques (spanning several hours) such as sol-gel or solidstate routes.

\section{Structural Aspects}

Oxides display a remarkable array of structural variations that could be visualized at different levels. At the outset, we can accommodate a particular structure within a mineral type such as perovskite, spinel, delafossite etc. Another approach derives from crystallographic examination and description of the solid-state arrangement in terms of a particular space group and unit cell dimensions. A localized ("inorganic chemist's") view considers the A-O or B-O clusters that are building blocks within the overall framework and the coordination environment around the $\mathrm{Cu}$ cations. All three descriptions are complementary and are adopted herein, see Tables IIa and IIb for the thirty-one compounds considered in this review.
The polyhedral representations are particularly illuminating in this regard, and we begin with the structure of the perovskite prototypea veritable "mother" of all structure types that are important in wide range of technological materials science applications. This is illustrated in Figure 4, with the $\mathrm{Cu}$ cation, the $\mathrm{B}$ cation, and the oxygens color coded the same way everywhere (c.f., Figure 1) for easy visualization. Rational and deliberate structure modifications, designed, to impart a certain characteristic (for example, a lowered optical bandgap), may be conveniently discussed with reference to this structural framework. Chemical alterations may be made either to the cationic sub-lattice or to the anionic framework (Figure 4). Thus the $\mathrm{B}$ cation or the oxygens in the perovskite structure may be substituted with another cation or anion with comparable ionic radii respectively. Nitrogen $\left(r_{\mathrm{N}}=1.5 \AA\right)$ readily substitutes for oxygen $\left(r_{\mathrm{O}}=\right.$ $1.4 \AA$ ) affording the corresponding oxynitrides, although note that the charges are not the same in the two cases. Rational and simultaneous chemical alterations of this sort, targeting both the sub-lattices, have been reported ${ }^{98}$ for $\mathrm{ABO}_{2} \mathrm{~N}$ type compounds, although such examples seem to be as yet sparse, for $\mathrm{Cu}$-based oxides. Indeed, the so-called heteroanionic systems (e.g., oxynitrides, oxysulfides $)^{99.100}$ have garnered much interest in recent years, spurred by applications in solar fuels, thermoelectrics etc. However, these mixed anionic compounds are beyond the scope of the present review.

If two B cations are within $\sim 15 \%$ of the size of one another, a range of solid solutions may be derived with interesting gradation in structural (e.g., unit cell dimension) or optical (energy bandgap, $\mathrm{E}_{\mathrm{g}}$ ) attributes. This behavior is exemplified by the $\mathrm{Cu}-\mathrm{Fe}-\mathrm{Cr}-\mathrm{O}$ system (Figures 5 and 6); these new materials were prepared via SCS by simple compositional tuning of the precursor mixture. Note that both the lattice parameter ( $\mathrm{a}, \mathrm{b}$ with black and $\mathrm{c}$ with blue traces in Figure 5) and $E_{g}$ value (Figures 6) vary, albeit not in the same manner - the change in $\mathrm{E}_{\mathrm{g}}$ with the extent of substitution, $\mathrm{x}$ being much more drastic (c.f., Figures $5 \mathrm{~b}$ and $6 \mathrm{~b}$ ). The linear change of the lattice parameter with composition confirmed that this ternary alloy followed Vegard's law. ${ }^{101}$

It is worth noting that literature examples of solid solutions within the ternary compound space are not as common as within the binary compound space. Therefore, these new and interesting examples provide a guiding template for future studies on chemical compositionproperty relationships.

Consider now the structures of the two parents: $\mathrm{Cu}_{2} \mathrm{O}$ and $\mathrm{CuO}$ (Figures $7 \mathrm{a}$ and $7 \mathrm{~b}$ respectively). The unit cells are also superimposed on the ball-and-stick representation in the two cases as dotted lines. While the $\mathrm{Cu}_{2} \mathrm{O}$ structure consists of a cubic unit cell, it is hexagonal for the $\mathrm{CuO}$ case. The local coordination geometry is also clearly seen to differ switching from linear in the former case to tetrahedral in the latter. Further structure details may be found for $\mathrm{Cu}_{2} \mathrm{O}$ in a preceding review article. ${ }^{6}$ Table II lists all the crystallographic attributes for the two parent structures as well as the 31 derivatives considered in this study.

Delafossites (Figure 8) are an important structural type for the $\mathrm{Cu}(\mathrm{I})$ case and several of these were also considered by previous authors ${ }^{6}$ therefore, their discussion is much abbreviated here. Interestingly, variant local coordination environments for the two cations are seen in the structural framework: linear for $\mathrm{Cu}(\mathrm{I})$ but octahedral for the B(III) cation. This structure type is observed for $\mathrm{CuBO}_{2}$ (B $=\mathrm{Rh}, \mathrm{Fe}, \mathrm{Al})$ (Table IIa). By contrast, the two cations experience a similar pyramidal coordination environment in the wurtzite structure (not shown), typical of $\mathrm{CuGaO}_{2}$.

The structures of the other $\mathrm{Cu}(\mathrm{I})$ based oxides with $\mathrm{Nb}$, Ta, or $\mathrm{V}$ as the B cation (see Table IIa) have been extensively discussed elsewhere by previous authors, ${ }^{6}$ and therefore are not further considered here. Instead, we now turn to structures based on $\mathrm{Cu}(\mathrm{II})$ : two common structure types are spinels and wolframite, shown in Figures 9a and $9 \mathrm{~b}$ respectively. Copper-containing spinels with the general chemical formula, $\mathrm{CuB}_{2} \mathrm{O}_{4}$, have a tetragonal unit cell while $\mathrm{Cu}$-containing wolframites (general formula: $\mathrm{CuBO}_{4}$ ) possess a unit cell of much lower symmetry: either, monoclinic or triclinic, depending on the particular compound (Table IIb). Once again, the local coordination 
Table II. Structural details of copper(I)- and copper(II)-based oxides.

Cell parameters

\begin{tabular}{|c|c|c|c|c|c|c|c|c|c|c|c|c|c|}
\hline \multirow{2}{*}{ No. } & \multirow[b]{2}{*}{ Compound } & \multirow[b]{2}{*}{ Structure type } & \multirow[b]{2}{*}{ Crystal system } & \multirow[b]{2}{*}{ ICSD \# } & \multirow[b]{2}{*}{ PDF card \# } & \multirow[b]{2}{*}{ Space group } & \\
\hline & & & & & & & $a(\AA)$ & $b(\AA)$ & $c(\AA)$ & $\alpha(\mathrm{deg})$ & $\beta(\operatorname{deg})$ & $\gamma(\mathrm{deg})$ & $\mathrm{V}\left(\AA^{3}\right)$ \\
\hline \multicolumn{14}{|c|}{ a) Copper(I) oxide-based } \\
\hline 1 & $\mathrm{CuAlO}_{2}$ & Delafossite & Trigonal & 31701 & 01-075-1988 & $R \overline{3} m(166)$ & 2.8604 & 2.8604 & 16.953 & 90.00 & 90.00 & 120.00 & 120.12 \\
\hline 2 & $\mathrm{CuCrO}_{2}$ & Delafossite & Trigonal & 402290 & 01-089-6744 & $R \overline{3} m(166)$ & 2.9734 & 2.9734 & 17.1000 & 90.00 & 90.00 & 120.00 & 130.93 \\
\hline 3 & $\mathrm{CuFeO}_{2}$ & Delafossite & Trigonal & 92184 & $01-070-6670$ & $R \overline{3} m(166)$ & 3.03328 & 3.03328 & 17.16019 & 90.00 & 90.00 & 120.00 & 136.73 \\
\hline 4 & $\alpha-\mathrm{CuGaO}_{2}$ & Delafossite & Trigonal & 60846 & 01-077-2495 & $R \overline{3} m(166)$ & 2.977 & 2.977 & 17.171 & 90.00 & 90.00 & 120.00 & 131.79 \\
\hline 5 & $\beta-\mathrm{CuGaO}_{2}$ & Wurtzite & Orthorhombic & 291233 & - & $\operatorname{Pna2}_{1}$ (33) & 5.46004 & 6.61013 & 5.27417 & 90.00 & 90.00 & 90.00 & 190.35 \\
\hline 6 & $\mathrm{CuNbO}_{3}$ & - & Monoclinic & 201899 & 01-084-0971 & $C 2 / m(12)$ & 9.488 & 8.44 & 6.763 & 90.00 & 90.93 & 90.00 & 541.5 \\
\hline 7 & $\mathrm{CuNb}_{3} \mathrm{O}_{8}$ & - & Monoclinic & 14099 & 01-071-1927 & $P 2_{1} / c$ (14) & 15.365 & 5.0717 & 7.5266 & 90.00 & 107.18 & 90.00 & 560.35 \\
\hline 8 & $\mathrm{Cu}_{2} \mathrm{Nb}_{8} \mathrm{O}_{21}$ & - & Monoclinic & $\begin{array}{l}\text { Not found in } \\
\text { ICSD database }\end{array}$ & - & $C 2 / m(12)$ & 10.5325 & 6.4306 & 10.173 & 90.00 & 100.212 & 90.00 & 678.11 \\
\hline 9 & $\mathrm{CuRhO}_{2}$ & Delafossite & Trigonal & 29214 & $01-075-0521$ & $R \overline{3} m(166)$ & 3.075 & 3.075 & 17.165 & 90.00 & 90.00 & 120.00 & 140.56 \\
\hline 10 & $\alpha-\mathrm{Cu}_{2} \mathrm{Ta}_{4} \mathrm{O}_{11}$ & - & Monoclinic & 252576 & - & $C c(9)$ & 10.7337 & 6.2506 & 12.8869 & 90.00 & 106.07 & 90.00 & 830.82 \\
\hline 11 & $\beta-\mathrm{Cu}_{2} \mathrm{Ta}_{4} \mathrm{O}_{11}$ & - & Trigonal & 72179 & 01-081-0815 & $R \overline{3} c(167)$ & 6.23 & 6.23 & 37.34 & 90.00 & 90.00 & 120.00 & 1255.11 \\
\hline 12 & $\mathrm{Cu}_{3} \mathrm{Ta}_{7} \mathrm{O}_{19}$ & - & Hexagonal & 247277 & - & $P 6_{3} / m(176)$ & 6.2278 & 6.2278 & 20.1467 & 90.00 & 90.00 & 120.00 & 676.71 \\
\hline 13 & $\mathrm{Cu}_{5} \mathrm{Ta}_{11} \mathrm{O}_{30}$ & - & Hexagonal & 421398 & $01-075-2355$ & $P \overline{6} 2 c(190)$ & 6.2297 & 6.2297 & 32.55 & 90.00 & 90.00 & 120.00 & 1094.00 \\
\hline 14 & $\mathrm{Cu}_{3} \mathrm{VO}_{4}$ & Stannite & Tetragonal & 418372 & - & $I \overline{4} 2 m(121)$ & 4.57531 & 4.57531 & 8.9918 & 90.00 & 90.00 & 90.00 & 188.23 \\
\hline \multicolumn{14}{|c|}{ b) Copper(II) oxide-based } \\
\hline 1 & $\mathrm{CuAl}_{2} \mathrm{O}_{4}$ & Spinel & Cubic & 9558 & 01-071-0967 & $F d \overline{3} m(227)$ & 8.078 & 8.078 & 8.078 & 90.00 & 90.00 & 90.00 & 527.12 \\
\hline 2 & $\mathrm{CuBi}_{2} \mathrm{O}_{4}$ & $\begin{array}{l}\text { Kusachiite } \\
\text { (Spinel) }\end{array}$ & Tetragonal & 71313 & 01-080-2489 & $P 4 / n c c$ (130) & 8.5019 & 8.5019 & 5.8196 & 90.00 & 90.00 & 90.00 & 420.65 \\
\hline 3 & $\mathrm{CuCo}_{2} \mathrm{O}_{4}$ & Spinel & Cubic & 36356 & 01-076-1887 & $F d \overline{3} m(227)$ & 8.105 & 8.105 & 8.105 & 90.00 & 90.00 & 90.00 & 532.43 \\
\hline 4 & $\mathrm{CuCr}_{2} \mathrm{O}_{4}$ & Spinel & Tetragonal & 16708 & 01-072-1212 & $I \overline{4} 2 d(122)$ & 6.04 & 6.04 & 7.78 & 90.00 & 90.00 & 90.00 & 283.83 \\
\hline 5 & $\mathrm{CuFe}_{2} \mathrm{O}_{4}$ & Spinel & Tetragonal & 16666 & 01-072-1174 & $I 4_{1} /$ amd $(141)$ & 5.81 & 5.81 & 8.71 & 90.00 & 90.00 & 90.00 & 294.02 \\
\hline 6 & $\mathrm{CuGa}_{2} \mathrm{O}_{4}$ & Spinel & Cubic & 61028 & 01-078-0172 & $F d \overline{3} m(227)$ & 8.298 & 8.298 & 8.298 & 90.00 & 90.00 & 90.00 & 571.37 \\
\hline 7 & $\mathrm{CuMn}_{2} \mathrm{O}_{4}$ & Spinel & Tetragonal & 9812 & 01-071-1142 & I4 ${ }_{1} /$ amd $(141)$ & 5.818 & 5.818 & 8.658 & 90.00 & 90.00 & 90.00 & 293.07 \\
\hline 8 & $\mathrm{CuMoO}_{4}$ & - & Triclinic & 22276 & 01-073-0488 & $P \overline{1}(2)$ & 9.903 & 6.783 & 8.359 & 101.08 & 96.88 & 107.05 & 517.44 \\
\hline 9 & $\mathrm{CuNb}_{2} \mathrm{O}_{6}$ & Columbite & Monoclinic & 81046 & 01-086-0348 & $P 2_{1} / c$ (14) & 4.9991 & 14.1566 & 5.754 & 90.00 & 91.718 & 90.00 & 407.03 \\
\hline 10 & $\mathrm{Cu}_{3} \mathrm{Nb}_{2} \mathrm{O}_{8}$ & - & Triclinic & - & 00-033-0476 & $P \overline{1}(2)$ & 5.178 & 5.785 & 6.007 & 100.46 & 83.498 & 65.701 & 148.14 \\
\hline 11 & $\mathrm{CuV}_{2} \mathrm{O}_{6}$ & - & Triclinic & 28151 & 01-074-2117 & $P \overline{1}(2)$ & 9.168 & 3.543 & 6.478 & 100.46 & 96.59 & 120.33 & 196.90 \\
\hline 12 & $\alpha-\mathrm{Cu}_{2} \mathrm{~V}_{2} \mathrm{O}_{7}$ & Blossite & Orthorhombic & 40973 & 01-073-2487 & $F d d 2$ (43) & 20.676 & 8.392 & 6.446 & 90.00 & 90.00 & 90.00 & 1118.46 \\
\hline 13 & $\beta-\mathrm{Cu}_{2} \mathrm{~V}_{2} \mathrm{O}_{7}$ & Ziesite & Monoclinic & 158375 & $01-076-2820$ & $C 2 / c(15)$ & 7.689 & 8.0289 & 10.1065 & 90.00 & 110.252 & 90.00 & 585.35 \\
\hline 14 & $\beta-\mathrm{Cu}_{3} \mathrm{~V}_{2} \mathrm{O}_{8}$ & Pseudolyonsite & Monoclinic & 27310 & 01-074-1503 & $P 2_{1} / c$ (14) & 6.2493 & 7.9936 & 6.3776 & 90.00 & 111.49 & 90.00 & 296.44 \\
\hline 15 & $\gamma-\mathrm{Cu}_{3} \mathrm{~V}_{2} \mathrm{O}_{8}$ & Mcberneyite & Triclinic & 27184 & 01-074-1401 & $P \overline{1}(2)$ & 5.196 & 5.355 & 6.505 & 69.22 & 88.69 & 68.08 & 155.73 \\
\hline 16 & $\mathrm{Cu}_{11} \mathrm{~V}_{6} \mathrm{O}_{26}$ & Fingerite & Triclinic & 201626 & 01-084-0733 & $P \overline{1}(2)$ & 8.1576 & 8.2691 & 8.0437 & 107.144 & 91.389 & 106.441 & 493.84 \\
\hline 17 & $\mathrm{CuWO}_{4}$ & $\begin{array}{l}\text { Distorted } \\
\text { wolframite }\end{array}$ & Triclinic & 16009 & 01-072-0616 & $P \overline{1}(2)$ & 4.7026 & 5.8389 & 4.8784 & 91.677 & 92.469 & 82.805 & 132.73 \\
\hline
\end{tabular}




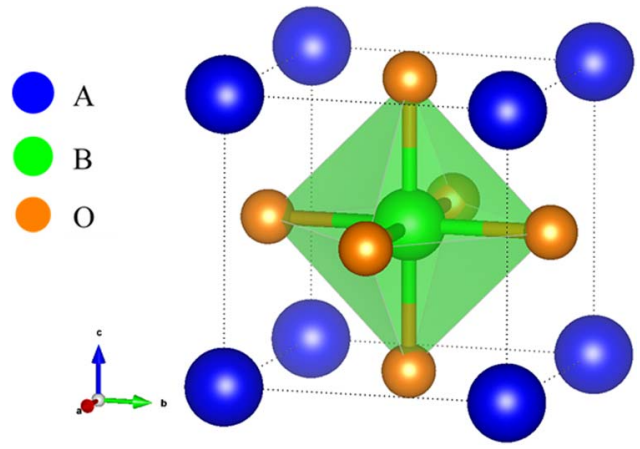

Figure 4. The perovskite structure; the unit cell is shown as a dotted line.

geometries are distinctly different for the two types of cations in the structure in both cases shown in Figures 9. In spinel structures, the $\mathrm{Cu}$ (II) species occupy the tetrahedral sites while the $\mathrm{B}$ (III) cations occupy the octahedral sites. On the other hand, both $\mathrm{Cu}(\mathrm{II})$ and $\mathrm{B}(\mathrm{VI})$ are found in octahedral geometry. Distortions from perfect geometry are common in these structures, as exemplified by $\mathrm{CuWO}_{4} .{ }^{94}$

$\mathrm{The} \mathrm{Cu}-\mathrm{V}-\mathrm{O}$ ternary system offers a remarkably diverse array of structures, particularly for the $\mathrm{Cu}$ (II) case. Thus the crystal structures of three $\mathrm{Cu}(\mathrm{II})$ compounds, namely, $\mathrm{CuV}_{2} \mathrm{O}_{6}, \mathrm{Cu}_{2} \mathrm{~V}_{2} \mathrm{O}_{7}$, and $\mathrm{Cu}_{3} \mathrm{~V}_{2} \mathrm{O}_{8}$ are shown in Figures 10-12; recall that these are the 1:1, 2:1 and 3:1 combinations of $\mathrm{CuO}$ and $\mathrm{V}_{2} \mathrm{O}_{5}$ (c.f., Table $\mathrm{Ib}$ and Figure $2 \mathrm{~b}$ above). Interestingly, the $\mathrm{Cu}$ (II) cations are in three distinctly different coordination environments in the three cases: octahedral $\mathrm{CuO}_{6}$ in $\mathrm{CuV}_{2} \mathrm{O}_{6}$ (Figure 10a), (distorted) trigonal octahedral, $\mathrm{CuO}_{5}$ in $\alpha$ $\mathrm{Cu}_{2} \mathrm{~V}_{2} \mathrm{O}_{7}$ (Figure 11), and planar $\mathrm{CuO}_{4}$ in $\gamma-\mathrm{Cu}_{3} \mathrm{~V}_{2} \mathrm{O}_{8}$ (Figures 12). By contrast, $\mathrm{V}^{5+}$ occurs as $\mathrm{VO}_{6}$ or $\mathrm{VO}_{4}$ clusters in the three cases.

Phase transitions have been studied in the $\mathrm{Cu}-\mathrm{V}-\mathrm{O}$ ternary system since the 1960s. ${ }^{102,103}$ Polymorphs of both $\mathrm{Cu}_{2} \mathrm{~V}_{2} \mathrm{O}_{7}$ and $\mathrm{Cu}_{3} \mathrm{~V}_{2} \mathrm{O}_{8}$ are shown in Figures 11 and 12 respectively. These have been observed in recent SCS studies (as yet, unpublished) in our laboratories, and have been studied by thermal analysis and high-temperature XRD by previous authors. ${ }^{102,103}$ Three polymorphs are known and their transitions (often reversible) occur at temperatures ranging from $\sim$ $500^{\circ} \mathrm{C}$ to $\sim 700^{\circ} \mathrm{C}$. Other examples of polymorphism may be found in Table II. The wurtzite-derived $\beta-\mathrm{CuGaO}_{2}$ structure has been studied using synchrotron $\mathrm{X}$-ray radiation. ${ }^{28}$ This structure irreversibly transforms to the delafossite $\alpha$-phase at temperatures higher than $\sim 460^{\circ} \mathrm{C}$ in an $\mathrm{Ar}$ atmosphere. ${ }^{28}$ In general, there is much scope for similar detailed studies on phase transitions in ternary copper oxides. It is also worth noting that the impact of these polymorphs on the corresponding optoelectronic characteristics, has not been adequately explored.

Other interesting structural questions remain, at least on a semantic level. For example, one can envision a thought experiment wherein the two component binary oxide structures are completely dismantled and then reassembled into a ternary compound framework. What dictates the ultimate crystal structure and does that have a relationship to the initial binary compound structures?
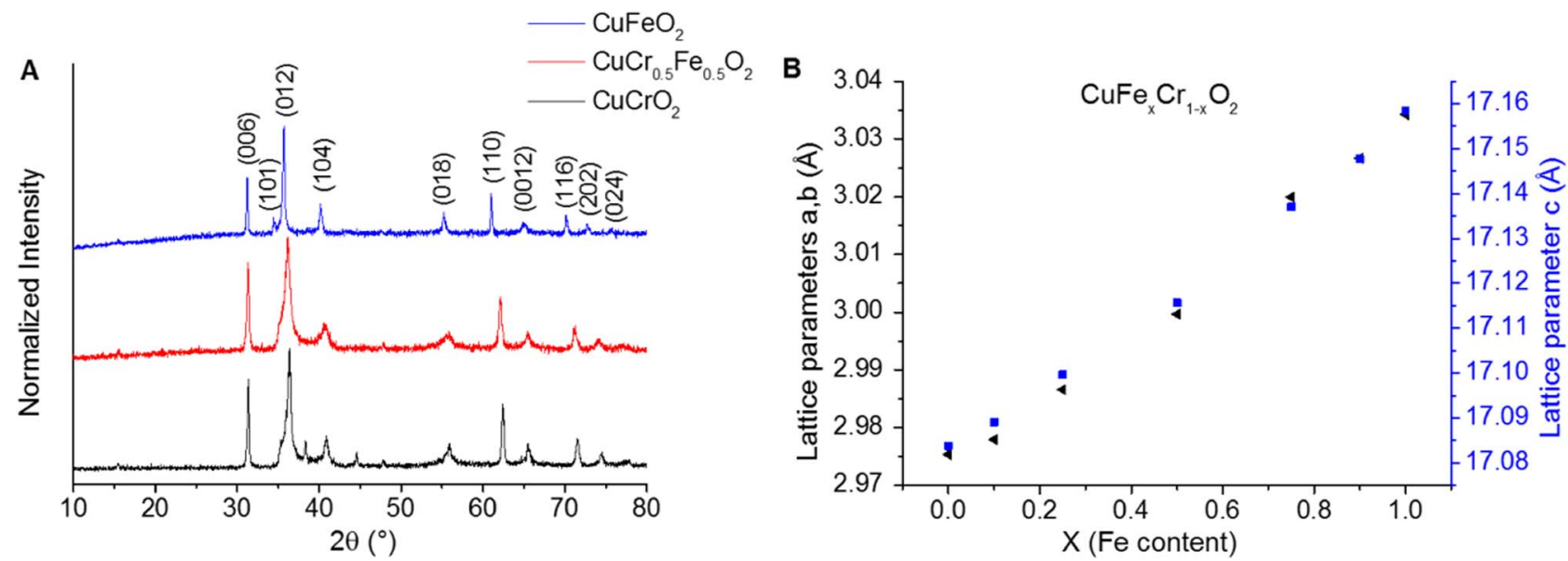

Figure 5. X-ray powder diffractograms for $\mathrm{CuFeO}_{2}, \mathrm{CuCr}_{0.5} \mathrm{Fe}_{0.5} \mathrm{O}_{2}$, and $\mathrm{CuCrO}_{2}$ (A) Lattice parameter dependence on solid solution composition (B). (Unpublished results.).
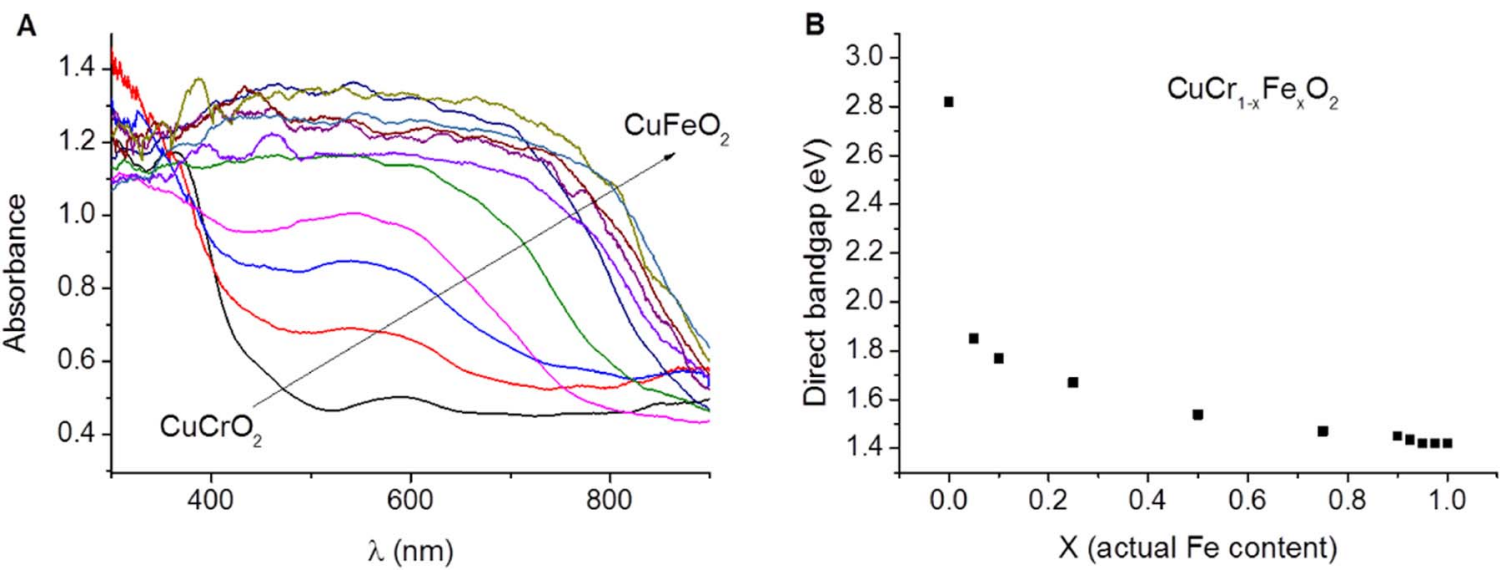

Figure 6. UV-vis spectra for the $\mathrm{CuCr}_{1-\mathrm{x}} \mathrm{Fe}_{\mathrm{x}} \mathrm{O}_{2}$ alloys (A). Direct bandgap values for the solid solutions (as derived from Tauc plots) and their dependence on composition (B). (Unpublished results.). 
(a)

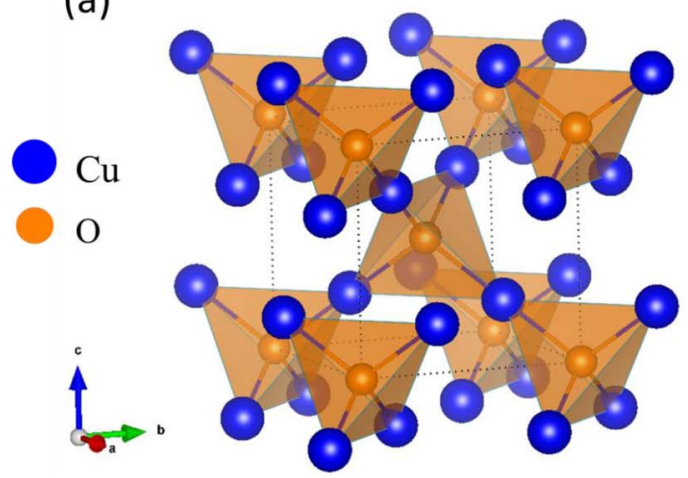

(b)

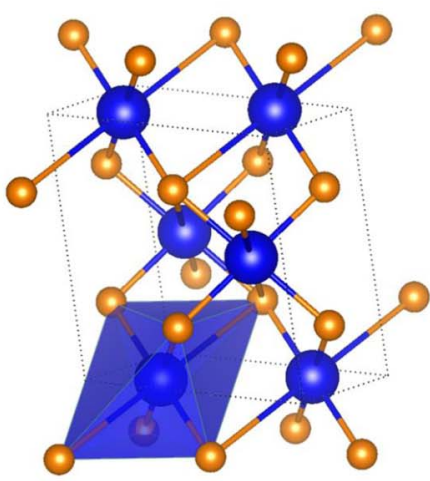

Figure 7. Crystal structures of the parent oxides: $\mathrm{Cu}_{2} \mathrm{O}(\mathrm{a})$ and $\mathrm{CuO}$ (b); as in Fig. 4, the unit cells are shown as dotted lines.

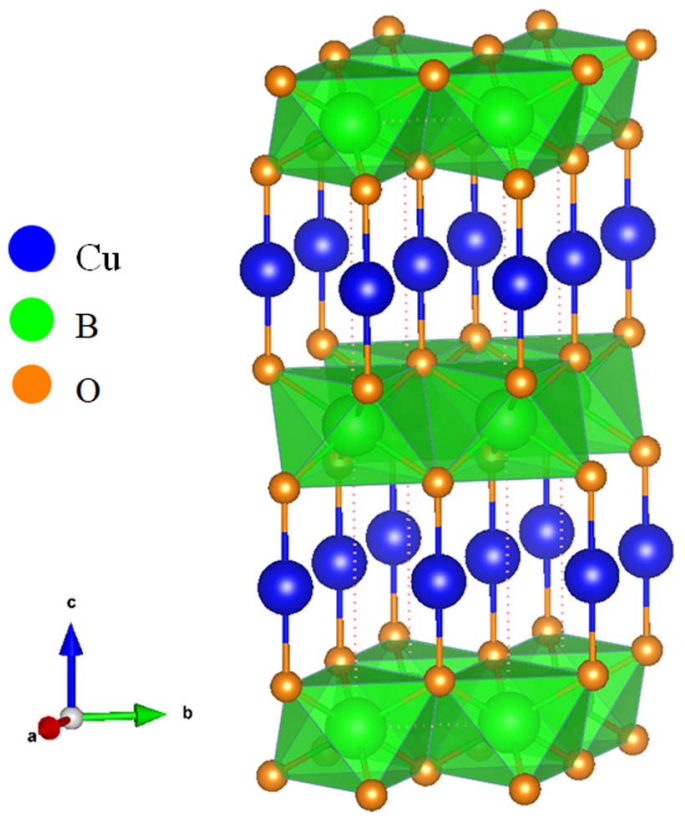

Figure 8. The delafossite crystal structure type.

\section{Optoelectronic Aspects}

Being semiconductors, an important optoelectronic property is the optical bandgap value, $\mathrm{E}_{\mathrm{g}}$. Other details on the nature of the optical transition, whether direct or indirect, has a bearing on the strength of

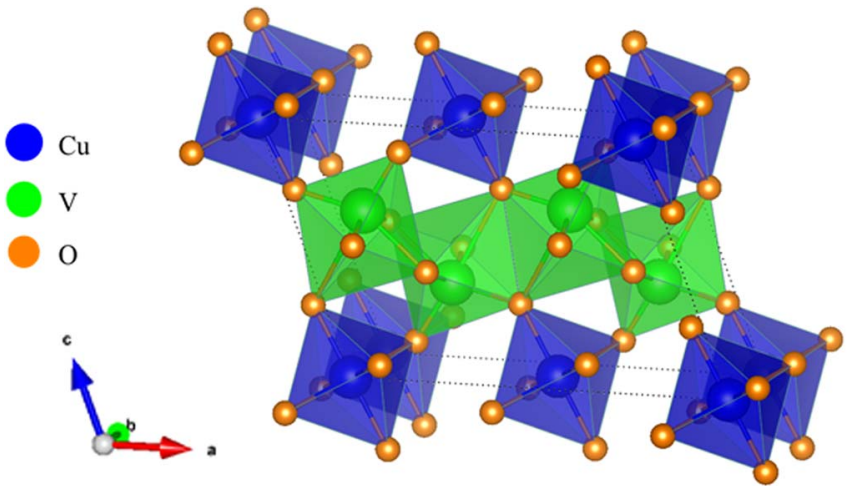

Figure 10. Crystal structure of $\mathrm{CuV}_{2} \mathrm{O}_{6}$; unit cell shown as dotted line.

absorption of the excitation light by the semiconductor. Tables IIIa and IIIb assemble the available data on the 31 compounds. Methods for estimating $E_{\mathrm{g}}$ have been reviewed elsewhere; ${ }^{104}$ two of these are shown under the categories: "Absorption edge" and "Tauc plot" respectively. Again, for reasons outlined elsewhere, ${ }^{104}$ values derived from the latter are considered to be more reliable. Nonetheless, in cases where both methods have been used, the two sets of results are in reasonable accord (see entry \#2 in Table IIIb, for example). Copper tungstate and niobate are exceptions to this trend and considerable variability (as much as $1 \mathrm{eV}$ or more!) exists in the reported values for reasons, again discussed elsewhere. ${ }^{104}$ The $\mathrm{E}_{\mathrm{g}}$ values have been quoted to varying precision between 2 and 3 significant figures in Table III. Given the variability, however, only 2 significant figures may be justifiable. It is worth noting that, with rare exceptions, the vast majority of the $\mathrm{E}_{\mathrm{g}}$ (a)

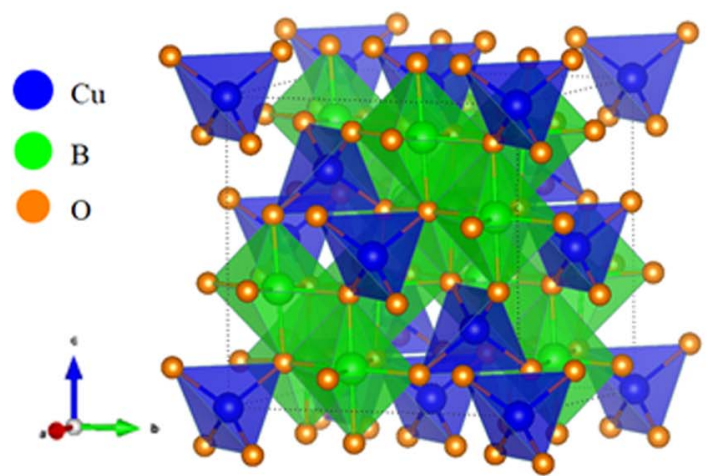

(b)

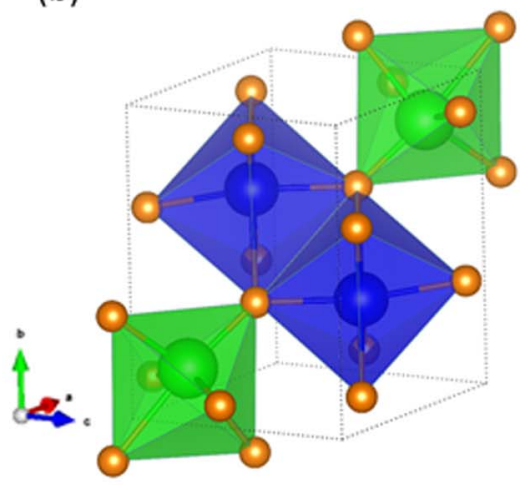

Figure 9. Crystal structures of the spinel (a) and wolframite (b) types; unit cells shown as dotted lines in both cases. 
(a)

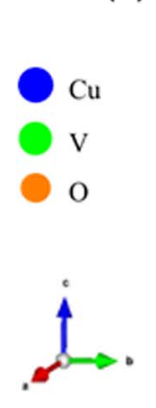

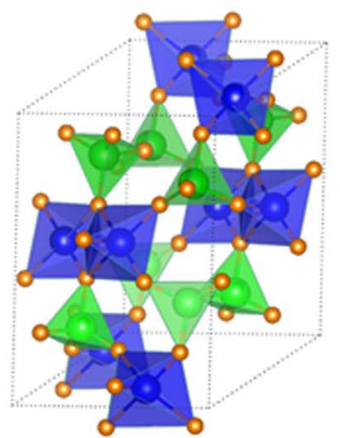

(b)

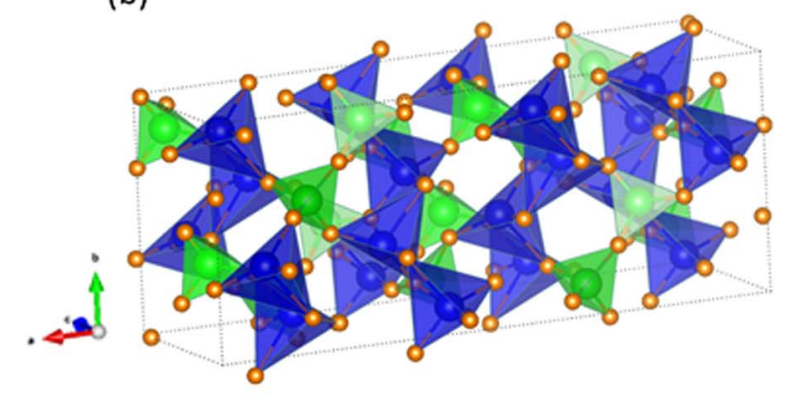

Figure 11. Crystal structures of two polymorphs of $\mathrm{Cu}_{2} \mathrm{~V}_{2} \mathrm{O}_{7}$ : The $\beta$ - (a) and $\alpha$-modifications (b) are shown. Unit cells are shown as dotted lines.

values also lie within the "sweet spot" of optimal overlap with the solar spectrum.

Many of the compounds listed in Table III feature both types of optical transitions; therefore two separate sets of values for $E_{g}$ have been listed. However, unlike in the notable case of $\mathrm{BiVO}_{4}$, few questions have been raised on the nature of the fundamental bandgap in these materials. While theory can contribute much to an understanding electronic band structures, we have avoided consideration of theoretically-derived $\mathrm{E}_{\mathrm{g}}$ values for the compilations in Table III. Accurate prediction of $E_{\mathrm{g}}$ values remains an Achilles heel of methods such as DFT, although improvements may be anticipated in the future.

As in the preceding section, interesting questions remain on the electronic nature of the resultant ternary structures after they are assembled from the binary components. Unlike in the case of solid solutions of the two components (c.f., Figure $5 b$ ), the $E_{g}$ values for the ternaries are not bracketed by the values for the end (binary) members. Another way of looking at this is to appreciate that in many cases, the $\mathrm{B}$ oxide is not even a semiconductor. A case in point is entry \#1 in Tables $\mathrm{Ia}$ and $\mathrm{Ib}$ above: $\mathrm{Al}_{2} \mathrm{O}_{3}$ is an insulator. In other cases, e.g., entry \#7 in Table Ib, the B oxide is an electronic conductor. In most of the cases, however, the B oxide indeed is a semiconductor.

Bonding or electronic band structure theory can contribute much to an understanding of how the ternary (or higher) compound band structures involve from the binary compound cases. For example, distortions in the cation or oxygen tetrahedra have been considered as a function of the $r_{\mathrm{M}(\mathrm{I})} / r_{\mathrm{M}(\mathrm{III})}$ ratio in the $\beta-\mathrm{NaFeO}_{2}$ structure (characteristic of wurtzite-derived $\left.\beta-\mathrm{CuGaO}_{2}\right){ }^{28}$ This distortion influences the energy splitting of d-orbitals in compounds containing the $\mathrm{Cu}(\mathrm{I})$ species, and in these cases, the $\mathrm{Cu} 3 \mathrm{~d}$ orbitals strongly contribute to the top of the valence band. In general, the role of ions such as $\mathrm{Cu}^{+}$(or $\mathrm{Ag}^{+}$) for that matter, as an effective electronic structure regulator, has been the topic of much recent interest in the PEC and photocatalysis communities. ${ }^{105}$ This is because these ions affect the fundamental na- ture of the optical transition from the valence band to the conduction band. Strategies for "optoelectronic engineering" of the band structure to intensify the light absorption strength or even the nature of the optical transition (e.g., switch from indirect to direct), are only at a rudimentary level at present. Such efforts (e.g., doping with a rare earth element) have been attempted only with binary oxides, at least to our knowledge.

Carrier transport through the semiconductor bulk follows after the initial optical excitation of the inorganic semiconductor. The dynamics of this process exerts much influence on the overall efficiency of the energy conversion or catalysis process. In most instances (unless we are considering devices of the dye-sensitized variety), it is the minority carrier diffusion length $\left(\mathrm{L}_{\mathrm{D}}\right)$ that is the crucial parameter. The larger the $L_{D}$ value is, the better is the material quality in terms of defects, traps etc. Thus for an $n$-type semiconductor, holes are the minority carriers while electrons are the minority carriers for $p$-type materials. Unfortunately, data on $\mathrm{L}_{\mathrm{D}}$ appear to be rather sparse of the compounds considered in this review.

One exception to this trend is the $\mathrm{Cu}(\mathrm{II})$ ternary oxide, $\mathrm{CuBi}_{2} \mathrm{O}_{4}$. Time-resolved microwave conductivity (TRMC) and surface photovoltage (SPV) measurements were performed to assess the optoelectronic quality of this semiconductor. ${ }^{52}$ The TRMC transient decays showed the presence of two time constants leading to $\mathrm{L}_{\mathrm{D}}$ values of $\sim 10 \mathrm{~nm}$ and $\sim 52 \mathrm{~nm}$ respectively. ${ }^{52}$ The coincidence of the SPV signal onset with the optical bandgap cut off wavelength was interpreted to signal the absence of optically active defects in the material. ${ }^{52}$ The electrical transport mechanism has been studied and modeled as variable range small-polaron hopping at low temperatures (below $300 \mathrm{~K}$ ) and phonon-assisted small polaron hopping at high temperatures. ${ }^{106}$ In general, the need for more studies (both experimental and theoretical) aimed at understanding charge transport mechanism(s) in $\mathrm{CuBi}_{2} \mathrm{O}_{4}$, has been stressed in the literature. ${ }^{52}$ The situation is even more pressing for the other 30 compounds in Table I.
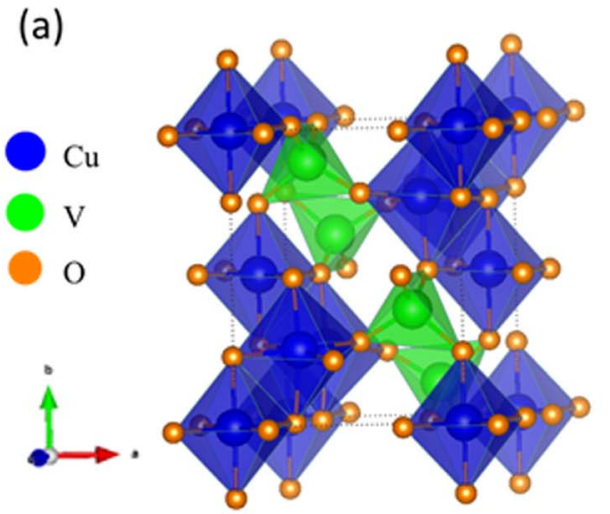

(b)

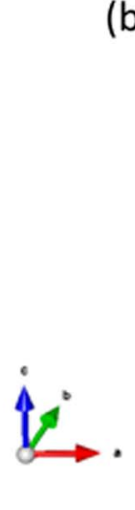

Figure 12. As in Figure 11 but for $\beta-\mathrm{Cu}_{3} \mathrm{~V}_{2} \mathrm{O}_{8}$ (a) and $\gamma-\mathrm{Cu}_{3} \mathrm{~V}_{2} \mathrm{O}_{8}$ (b). Unit cells are shown as dotted lines. 
Table III. Optical bandgaps for copper oxide-based ternary oxides. a) Copper (I)-based compounds. b) Copper(II)-based compounds.

\begin{tabular}{|c|c|c|c|c|c|}
\hline \multirow[b]{3}{*}{ No. } & \multirow[b]{3}{*}{ Oxide } & \multicolumn{3}{|c|}{ Optical bandgap (eV) } & \multirow[b]{3}{*}{ Ref. (s) } \\
\hline & & \multirow[b]{2}{*}{ Absorption edge } & \multicolumn{2}{|c|}{ Tauc plot } & \\
\hline & & & Direct transition & Indirect transition & \\
\hline \multicolumn{6}{|c|}{ a) Copper(I) oxide-based } \\
\hline 1 & $\mathrm{CuAlO}_{2}$ & - & 3.01 & 1.87 & 12 \\
\hline 2 & $\mathrm{CuCrO}_{2}$ & 3.1 & - & 1.32 & 16,17 \\
\hline 3 & $\mathrm{CuFeO}_{2}$ & 1.55 & 3.1 & 1.47 & 18,19 \\
\hline 6 & $\mathrm{CuNbO}_{3}$ & - & 2.09 & 1.89 & 30 \\
\hline 7 & $\mathrm{CuNb}_{3} \mathrm{O}_{8}$ & - & - & 1.26 & 31 \\
\hline 8 & $\mathrm{Cu}_{2} \mathrm{Nb}_{8} \mathrm{O}_{21}$ & - & $1.6-3.0$ & $1.43-1.65$ & 33 \\
\hline 9 & $\mathrm{CuRhO}_{2}$ & 1.9 & - & - & 34 \\
\hline 10 & $\alpha-\mathrm{Cu}_{2} \mathrm{Ta}_{4} \mathrm{O}_{11}$ & - & 2.7 & 2.6 & 35 \\
\hline 11 & $\beta-\mathrm{Cu}_{2} \mathrm{Ta}_{4} \mathrm{O}_{11}$ & - & 2.7 & 2.6 & 36 \\
\hline 1 & $\mathrm{CuAl}_{2} \mathrm{O}_{4}$ & 1.77 & 1.8 & - & 41,42 \\
\hline 2 & $\mathrm{CuBi}_{2} \mathrm{O}_{4}$ & $1.4-1.8$ & $1.48-1.80$ & $1.42-1.84$ & $45-55$ \\
\hline 3 & $\mathrm{CuCo}_{2} \mathrm{O}_{4}$ & - & $1.49-1.74$ & - & 58 \\
\hline 4 & $\mathrm{CuCr}_{2} \mathrm{O}_{4}$ & - & 1.40 & - & 66 \\
\hline 5 & $\mathrm{CuFe}_{2} \mathrm{O}_{4}$ & - & $1.24-1.42$ & - & 68,69 \\
\hline 6 & $\mathrm{CuGa}_{2} \mathrm{O}_{4}$ & - & $\sim 1.7$ & - & 70 \\
\hline 7 & $\mathrm{CuMn}_{2} \mathrm{O}_{4}$ & - & - & 1.4 & 71 \\
\hline 8 & $\mathrm{CuMoO}_{4}$ & - & $\sim 2.8$ & - & 72 \\
\hline 9 & $\mathrm{CuNb}_{2} \mathrm{O}_{6}$ & - & - & 1.77 & 74 \\
\hline 10 & $\mathrm{Cu}_{3} \mathrm{Nb}_{2} \mathrm{O}_{8}$ & 2.5 & - & - & 75 \\
\hline 11 & $\mathrm{CuV}_{2} \mathrm{O}_{6}$ & - & - & 1.96 & 76 \\
\hline 12 & $\alpha-\mathrm{Cu}_{2} \mathrm{~V}_{2} \mathrm{O}_{7}$ & - & - & $1.9 \pm 0.1$ & 79 \\
\hline 13 & $\beta-\mathrm{Cu}_{2} \mathrm{~V}_{2} \mathrm{O}_{7}$ & - & - & 1.98 & 76 \\
\hline
\end{tabular}

Indirect insights into the optoelectronic characteristics may be gleaned from photoelectrochemical and photocatalytic activity measurements; these are considered next.

\section{Photoelectrochemical and Photocatalytic Aspects}

At the outset, it is worth mentioning that comparisons of the efficacy of a given photoelectrode (or photocatalyst powder) material with other candidates in a given application, are immediately handicapped by the absence of an agreed-upon framework for reporting PEC data or a photocatalysis figure-of-merit. This stands in contrast to photovoltaic devices where such standards exist and cell efficiencies are certified. Nonetheless, with this caveat in mind, reported data on how the 31 ternary oxides fare in either water splitting, $\mathrm{CO}_{2}$ photoreduction, or pollutant degradation can still be made.

An immediate assessment of the photoelectrochemical quality of the oxide material may be obtained either via a photovoltammetry scan or by measuring the photocurrent at a fixed bias potential in a suitable aqueous medium. ${ }^{107}$ For an $n$-type material, the expectation is that the photocurrent arises from the (anodic) oxidation of solution species such as water (i.e., the oxygen evolution reaction (OER). For the $p$ type material in a de-oxygenated aqueous medium, the corresponding water-splitting reaction would be the hydrogen evolution reaction or HER. Such data on $13 \mathrm{Cu}(\mathrm{I})$-based ternary oxides were reported by previous authors (see Table I, Ref. 6); available data on the $\mathrm{Cu}$ (II) counterparts are contained in Table IV.

The above assumption of the source of the photocurrent rooted in OER or HER, hinges on the fact that the extent of photoelectro- chemical corrosion of the oxide semiconductor itself is negligible in the particular medium. This must be carefully verified by product (i.e., $\mathrm{O}_{2}$ or $\mathrm{H}_{2}$ ) collection and quantification, and comparison with the quantity expected from the charge passed (i.e., the current efficiency). In many of the cases in Table IV, this has not been done.

The other important variables in these data are the medium $\mathrm{pH}$ and the photon flux, both of which are specified in the compilation. Taken as a whole, $\mathrm{CuBi}_{2} \mathrm{O}_{4}$ is easily seen to outperform the other compounds, and the photocurrent level is at least an order of magnitude higher in this case (entry \#1, Table IV).

Table $\mathrm{V}$ lists instances where the OER data have indeed been reported in studies on copper-based ternary oxides. The entries in this tabulation all pertain to $\mathrm{Cu}$ (II)-based compounds. The faradaic efficiency values indeed approach $100 \%$ except at lower bias potentials (e.g., entries \# 1, 2 in Table V). Corresponding HER data are tabulated in Table VI, once again for $\mathrm{Cu}$ (II)-based ternary oxides. Unlike in Table $\mathrm{V}$, these performance metrics pertain to powder suspensions of the oxide and not photoelectrodes. Therefore, it is more difficult to assess the efficacy in these cases, given that faradaic efficiency values, obviously, are not accessible.

Finally, $\mathrm{CO}_{2}$ photoreduction data are summarized in Table VII; clearly, examples are rather sparce, especially for $\mathrm{Cu}$ (II)-based compounds. Both modes of operation, i.e., using photocathode (entry \#1) or using powder suspensions (entries \# 2,3) are considered in this tabulation on three ternary oxides based on $\mathrm{Cu}$ (II). A range of reduction products appear depending on the specific conditions used. 
Table IV. Performance of Cu(II)-based ternary oxides in water splitting.

\begin{tabular}{|c|c|c|c|c|c|c|c|c|c|}
\hline $\begin{array}{l}\text { Entry } \\
\text { No. }\end{array}$ & Oxide & Electrolytes & $\mathrm{pH}$ & $\begin{array}{l}\text { Light source and } \\
\text { intensity }\end{array}$ & $\begin{array}{l}\text { Photocurrent, } \\
|j| / \mu \mathrm{A} \mathrm{cm}^{-2}\end{array}$ & $\begin{array}{l}\text { Potential, } \\
\text { V vs RHE }\end{array}$ & $\begin{array}{l}\text { Semiconductor } \\
\text { type }\end{array}$ & Comments & Ref. \\
\hline 1 & $\mathrm{CuBi}_{2} \mathrm{O}_{4}$ & $\begin{array}{l}0.3 \mathrm{M} \mathrm{K}_{2} \mathrm{SO}_{4} \text { with } \\
0.2 \mathrm{M} \text { phosphate } \\
\text { buffer }\end{array}$ & 6.65 & Solar simulator & 2500 & 0.6 & $p$ & - & 56 \\
\hline 2 & $\mathrm{CuNb}_{2} \mathrm{O}_{6}$ & $\begin{array}{l}0.1 \mathrm{M} \mathrm{NaHCO}_{3} \\
\text { solution, bubbled } \\
\mathrm{CO}_{2}\end{array}$ & 7.0 & $\begin{array}{l}150 \mathrm{~W} \text { tungsten- } \\
\text { halogen }\end{array}$ & $\sim 150$ & 0.2 & $p$ & - & 74 \\
\hline 3 & $\mathrm{Cu}_{3} \mathrm{Nb}_{2} \mathrm{O}_{8}$ & $\begin{array}{l}0.5 \mathrm{M} \mathrm{NaHCO}_{3} \\
\text { solution, bubbled } \\
\mathrm{CO}_{2}\end{array}$ & 7.3 & Solar simulator & 180 & 0.3 & $p$ & - & 75 \\
\hline 4 & $\mathrm{CuV}_{2} \mathrm{O}_{6}$ & $\begin{array}{l}0.1 \mathrm{M} \text { borate } \\
\text { buffer with } 0.1 \mathrm{M} \\
\mathrm{Na}_{2} \mathrm{SO}_{3}\end{array}$ & 9.2 & $\begin{array}{l}150 \mathrm{~W} \text { xenon } \\
\text { lamp }\end{array}$ & $\sim 220$ & 1.58 & $n$ & - & 76 \\
\hline 5 & $\alpha-\mathrm{Cu}_{2} \mathrm{~V}_{2} \mathrm{O}_{7}$ & $\begin{array}{l}0.1 \mathrm{M} \text { borate } \\
\text { buffer with } 0.1 \mathrm{M} \\
\mathrm{Na}_{2} \mathrm{SO}_{3}\end{array}$ & 9.2 & $\begin{array}{l}385 \mathrm{~nm} \text { light } \\
\text { emitting diode, } \\
\text { illumination } \\
\text { power was } 3.0 \\
\mathrm{~mW}\end{array}$ & 600 & 1.0 & $n$ & $\begin{array}{l}\text { PEC was } \\
\text { performed in } \\
\text { scanning } \\
\text { droplet cell. }\end{array}$ & 77 \\
\hline \multirow[t]{2}{*}{6} & \multirow[t]{2}{*}{$\beta-\mathrm{Cu}_{2} \mathrm{~V}_{2} \mathrm{O}_{7}$} & $\begin{array}{l}0.1 \mathrm{M} \text { borate } \\
\text { buffer with } 0.1 \mathrm{M} \\
\mathrm{Na}_{2} \mathrm{SO}_{3}\end{array}$ & 9.2 & $\begin{array}{l}150 \mathrm{~W} \text { xenon } \\
\text { lamp }\end{array}$ & $\sim 120$ & 1.58 & $n$ & - & 76 \\
\hline & & $\begin{array}{l}0.1 \mathrm{M} \text { borate } \\
\text { buffer with } 0.1 \mathrm{M} \\
\mathrm{Na}_{2} \mathrm{SO}_{3}\end{array}$ & 9.2 & $\begin{array}{l}150 \mathrm{~W} \text { xenon } \\
\text { lamp }\end{array}$ & $\sim 40$ & 1.0 & $n$ & - & 76 \\
\hline \multirow[t]{3}{*}{7} & \multirow[t]{3}{*}{$\beta-\mathrm{Cu}_{3} \mathrm{~V}_{2} \mathrm{O}_{8}$} & $\begin{array}{l}0.1 \mathrm{M} \text { borate } \\
\text { buffer with } 0.1 \mathrm{M} \\
\mathrm{Na}_{2} \mathrm{SO}_{3}\end{array}$ & 9.2 & $\begin{array}{l}300 \mathrm{~W} \text { Xe arc } \\
\text { lamp }\end{array}$ & $\sim 100$ & 1.0 & $n$ & - & 82 \\
\hline & & $\begin{array}{l}0.1 \mathrm{M} \text { borate } \\
\text { buffer with } 0.1 \mathrm{M} \\
\mathrm{Na}_{2} \mathrm{SO}_{3}\end{array}$ & 9.2 & $\begin{array}{l}300 \mathrm{~W} \text { Xe arc } \\
\text { lamp }\end{array}$ & $\sim 150$ & 1.0 & $n$ & $\begin{array}{l}\text { Mo-doped } \\
\text { sample }\end{array}$ & 82 \\
\hline & & $\begin{array}{l}0.1 \mathrm{M} \text { borate } \\
\text { buffer with } 0.1 \mathrm{M} \\
\mathrm{Na}_{2} \mathrm{SO}_{3}\end{array}$ & 9.2 & $\begin{array}{l}300 \mathrm{~W} \text { Xe arc } \\
\text { lamp }\end{array}$ & $\sim 100$ & 1.0 & $n$ & $\begin{array}{l}\text { Cr-doped } \\
\text { sample }\end{array}$ & 83 \\
\hline \multirow[t]{2}{*}{8} & \multirow[t]{2}{*}{$\gamma-\mathrm{Cu}_{3} \mathrm{~V}_{2} \mathrm{O}_{8}$} & $\begin{array}{l}0.1 \mathrm{M} \text { borate } \\
\text { buffer with } 0.1 \mathrm{M} \\
\mathrm{Na}_{2} \mathrm{SO}_{3}\end{array}$ & 9.2 & $150 \mathrm{~W}$ Xe arc & 91 & 1.23 & $n$ & - & 84 \\
\hline & & $\begin{array}{l}0.1 \mathrm{M} \text { borate } \\
\text { buffer with } 0.1 \mathrm{M} \\
\mathrm{Na}_{2} \mathrm{SO}_{3}\end{array}$ & 9.2 & $\begin{array}{l}150 \mathrm{~W} \text { Xe arc } \\
\text { lamp }\end{array}$ & $\sim 53$ & 1.0 & $n$ & - & \\
\hline \multirow[t]{3}{*}{9} & \multirow[t]{3}{*}{$\mathrm{Cu}_{11} \mathrm{~V}_{6} \mathrm{O}_{26}$} & $\begin{array}{l}0.1 \mathrm{M} \text { borate } \\
\text { buffer with } 0.1 \mathrm{M} \\
\mathrm{Na}_{2} \mathrm{SO}_{3}\end{array}$ & 9.2 & $\begin{array}{l}300 \mathrm{~W} \text { Xe arc } \\
\text { lamp }\end{array}$ & 55 & 1.0 & $n$ & - & 85 \\
\hline & & $\begin{array}{l}0.1 \mathrm{M} \text { borate } \\
\text { buffer with } 0.1 \mathrm{M} \\
\mathrm{Na}_{2} \mathrm{SO}_{3}\end{array}$ & 9.2 & $\begin{array}{l}300 \mathrm{~W} \text { Xe arc } \\
\text { lamp }\end{array}$ & 85 & 1.0 & $n$ & $\begin{array}{l}\text { Mo-doped } \\
\text { sample }\end{array}$ & \\
\hline & & $\begin{array}{l}0.1 \mathrm{M} \text { borate } \\
\text { buffer with } 0.1 \mathrm{M} \\
\mathrm{Na}_{2} \mathrm{SO}_{3}\end{array}$ & 9.2 & $\begin{array}{l}300 \mathrm{~W} \text { Xe arc } \\
\text { lamp }\end{array}$ & 145 & 1.0 & $n$ & $\begin{array}{l}\text { W-doped } \\
\text { sample }\end{array}$ & \\
\hline 10 & $\mathrm{CuWO}_{4}$ & $\begin{array}{l}0.1 \mathrm{M} \text { potassium } \\
\text { phosphate }\end{array}$ & 7.0 & $\begin{array}{l}150 \mathrm{~W} \text { Xe arc } \\
\text { lamp }\end{array}$ & 200 & 1.23 & $n$ & - & 89 \\
\hline
\end{tabular}

${ }^{a}$ The light intensity was $100 \mathrm{~mW} \mathrm{~cm}{ }^{-2}$ in entries \#1-4 and in \#6-10.

Table V. Photoelectrochemical oxygen evolution on $\mathrm{Cu}(\mathrm{II})$-oxides.

\begin{tabular}{|c|c|c|c|c|c|c|}
\hline No. & Oxide & Medium & $\begin{array}{l}\text { Light } \\
\text { intensity }\end{array}$ & $\begin{array}{l}\text { Applied potential } \\
\text { bias (V vs RHE) }\end{array}$ & $\begin{array}{l}\text { Faradaic } \\
\text { efficiency (\%) }\end{array}$ & Ref. \\
\hline 1 & $\mathrm{CuV}_{2} \mathrm{O}_{6}$ & $0.1 \mathrm{M}$ borate buffer, $\mathrm{pH} 9.2$ & $300 \mathrm{mWcm}^{-2}$ & 1.58 & $70(20 \mathrm{~min})$ & 77 \\
\hline 2 & $\beta-\mathrm{Cu}_{2} \mathrm{~V}_{2} \mathrm{O}_{7}$ & & & 1.58 & $80(20 \mathrm{~min})$ & 77 \\
\hline 3 & $\beta-\mathrm{Cu}_{3} \mathrm{~V}_{2} \mathrm{O}_{8}(0.75 \mathrm{wt} \%$ Mo doped $)$ & & & 1.6 & $100(5 \mathrm{~min})$ & 83 \\
\hline 4 & $\mathrm{Cu}_{11} \mathrm{~V}_{6} \mathrm{O}_{26}$ (3\% Mo doped $)$ & $0.1 \mathrm{M}$ borate buffer with $0.1 \mathrm{M} \mathrm{Na}_{2} \mathrm{SO}_{3}, \mathrm{pH} 9.2$ & & 1.6 & $95(2 \mathrm{~h})$ & 86 \\
\hline 5 & $\mathrm{CuWO}_{4}$ & $0.1 \mathrm{M}$ potassium borate buffer, $\mathrm{pH} 7.0$ & & 1.23 & $96(3 \mathrm{~h})$ & 89 \\
\hline
\end{tabular}


Table VI. Photocatalytic HER data on $\mathrm{Cu}(\mathrm{II})$-oxide suspensions.

\begin{tabular}{|c|c|c|c|c|c|c|c|}
\hline No. & Oxide & Medium & $\begin{array}{l}\text { Catalyst loading } \\
(\mathrm{g} / \mathrm{L})\end{array}$ & Light source & $\begin{array}{l}\text { Gas evolution rate } \\
\left(\mu \mathrm{mol} \mathrm{mg}^{-1} \mathrm{~h}^{-1}\right)\end{array}$ & $\begin{array}{l}\text { Quantum yield } \\
(\%)\end{array}$ & Ref. \\
\hline 1 & $\mathrm{CuAl}_{2} \mathrm{O}_{4}$ & $\begin{array}{l}40 \mathrm{ml} \text { containing } \\
0.025 \mathrm{M} \mathrm{SO}_{3}{ }^{2-} \\
\text { and } 1.0 \mathrm{M} \mathrm{KOH}^{-}\end{array}$ & 1.25 & $\begin{array}{l}600 \mathrm{~W} \text { tungsten } \\
\text { lamp }\end{array}$ & 0.74 & 0.064 & 44 \\
\hline 2 & $\mathrm{CuBi}_{2} \mathrm{O}_{4}$ & $\begin{array}{l}100 \mathrm{ml} 0.075 \mathrm{M} \\
\mathrm{KI} \text { solutions } \\
\text { containing } 0.05 \mathrm{M} \\
\mathrm{NaH}_{2} \mathrm{PO}_{4} / 0.05 \mathrm{M} \\
\mathrm{Na}_{2} \mathrm{HPO}_{4}, \mathrm{pH} 7.2\end{array}$ & 0.5 & $\begin{array}{l}300 \mathrm{~W} \text { xenon } \\
\text { lamp }\end{array}$ & 0.32 & - & 51 \\
\hline 3 & $\mathrm{CuCo}_{2} \mathrm{O}_{4}$ & $\begin{array}{l}40 \mathrm{ml} \text { containing } \\
0.025 \mathrm{M} \mathrm{SO}_{3}{ }^{2-} \\
\text { and } 1 \mathrm{M} \mathrm{KOH}^{-}\end{array}$ & 1.25 & $\begin{array}{l}600 \mathrm{~W} \text { tungsten } \\
\text { lamp }\end{array}$ & 1.73 & 0.098 & 44 \\
\hline 4 & $\mathrm{CuCr}_{2} \mathrm{O}_{4}$ & $\begin{array}{l}40 \mathrm{ml} \text { containing } \\
0.025 \mathrm{M} \mathrm{S}_{2} \mathrm{O}_{3}{ }^{2-} \\
\text { with } 0.5 \mathrm{M} \mathrm{NaOH}\end{array}$ & 1.25 & $\begin{array}{l}600 \mathrm{~W} \text { tungsten } \\
\text { lamp }\end{array}$ & 0.49 & 0.2 & 60 \\
\hline 5 & $\mathrm{CuFe}_{2} \mathrm{O}_{4}$ & $\begin{array}{l}100 \mathrm{ml} \text { containing } \\
0.05 \mathrm{M} \text { oxalic acid }\end{array}$ & 1.0 & $\begin{array}{l}250 \mathrm{~W} \text { xenon } \\
\text { lamp }\end{array}$ & 9.0 & - & 67 \\
\hline 7 & $\mathrm{CuMn}_{2} \mathrm{O}_{4}$ & $\begin{array}{l}40 \mathrm{ml} \text { containing } \\
0.025 \mathrm{M} \mathrm{SO}_{3}^{2-} \\
\text { and } 1 \mathrm{M} \mathrm{KOH}^{2-}\end{array}$ & 1.25 & $\begin{array}{l}600 \mathrm{~W} \text { tungsten } \\
\text { lamp }\end{array}$ & 0.81 & 0.1 & 71 \\
\hline
\end{tabular}

Corresponding reports on the use of $\mathrm{Cu}(\mathrm{I})$-based ternaries for $\mathrm{CO}_{2}$ photoreduction are contained in Refs. 5 and 26. A more general review on flow-based $\mathrm{CO}_{2}$ photoreduction schemes, may be found in Ref. 108.

In general, the problems with the stability of $\mathrm{Cu}$-based oxide semiconductors have been addressed by rapidly transferring the photogenerated electrons to a second phase, for example, carbon. Carbon has the advantage that the injected electrons are rapidly delocalized in the $\pi$-electron manifold. Further, many forms of nanocarbons are available. Two recent example studies on $\mathrm{Cu}_{2} \mathrm{O}$, may be cited. ${ }^{109,110}$ Corresponding examples for ternary oxides are as yet lacking, at least to our knowledge.

A second type of application of inorganic oxide semiconductors is in pollutant degradation. For this environmental remediation, $n$-type semiconductors are better suited in that highly oxidizing species such as holes or hydroxyl radicals can be generated at the semiconductormedium interface. However, the potential for simultaneously treating reducible pollutants (such as toxic metal ions) also exists with heterogeneous photocatalysis, and this feature is a bonus that is not available with advanced oxidation processes (AOPs) based on ozone, $\mathrm{H}_{2} \mathrm{O}_{2}$, and the like.

Table VIII lists examples in the literature where $\mathrm{Cu}$ (II)-based ternary oxides have been deployed for such an application. All these examples concern the destruction of an azo dye such as methyl orange or methylene blue. While four of the reported cases show almost complete dye destruction (presumably to mineralized products), four other studies reveal only modest performance where amounts, even as low as only $\sim 42 \%$ of the initial dye was degraded. Even the simultaneous presence of $\mathrm{H}_{2} \mathrm{O}_{2}$, as a generator of reactive oxygen species (ROS) did not seem to have helped matters to a significant extent.

The combination of optoelectronic (i.e., bandgap) data and photoelectrochemical measurements (e.g., capacitance voltage or photoaction spectroscopy) allows us to map the band edge positions

Table VII. Use of $\mathrm{Cu}(\mathrm{II})$-based ternary oxides for $\mathrm{CO}_{2}$ photoreduction.

$\mathrm{PEC} \mathrm{CO}_{2}$ reduction

\begin{tabular}{|c|c|c|c|c|c|c|c|}
\hline No. & Oxide & Medium & Light intensity & $\begin{array}{l}\text { Applied potential } \\
\text { bias (V vs RHE) }\end{array}$ & Products detected & $\begin{array}{l}\text { Faradaic } \\
\text { efficiency }(\%)\end{array}$ & Ref. \\
\hline 1 & $\mathrm{Cu}_{3} \mathrm{Nb}_{2} \mathrm{O}_{8}$ & $\begin{array}{l}0.5 \mathrm{M} \mathrm{NaHCO}_{3}, \\
\text { pH } 7.3\end{array}$ & $100 \mathrm{mWcm}^{-2}$ & 0.43 & $\begin{array}{l}\mathrm{CO}, \mathrm{CH}_{4}, \\
\mathrm{HCOOH}, \\
\mathrm{CH}_{3} \mathrm{OH}, \mathrm{C}_{2} \mathrm{H}_{5} \mathrm{OH} \\
\text { and } \mathrm{HCOH}\end{array}$ & $9(20 \mathrm{~min})$ & 75 \\
\hline
\end{tabular}

\begin{tabular}{|c|c|c|c|c|c|c|c|}
\hline No. & $\begin{array}{l}\text { Oxide } \\
\text { (Co-catalyst) }\end{array}$ & Medium & Catalyst loading & Light source & Product (s) & Gas evolution rate & Ref. \\
\hline 2 & $\begin{array}{l}\mathrm{CuCo}_{2} \mathrm{O}_{4} \\
\left(\mathrm{Ru}(\mathrm{bpy})_{3}{ }^{2+}\right)\end{array}$ & $\begin{array}{l}\text { TEOA/water/ } \\
\text { acetonitrile } \\
(1 \mathrm{ml} / 2 \mathrm{ml} / 3 \mathrm{ml}) \\
\text { with } 1 \mathrm{~atm} \mathrm{CO} 2\end{array}$ & $20 \mathrm{mg}$ & $300 \mathrm{~W}$ Xe lamp & $\mathrm{CO}, \mathrm{H}_{2}$ & $\begin{array}{l}22.9 \mu \mathrm{mol} \mathrm{h}^{-1} \\
\mathrm{CO}, 5.0 \mu \mathrm{mol} \mathrm{h}^{-1} \\
\mathrm{H}_{2}\end{array}$ & 57 \\
\hline 3 & $\mathrm{CuFe}_{2} \mathrm{O}_{4}$ & $\begin{array}{l}300 \mathrm{ml} \text { containing } \\
1.2 \mathrm{~g} \mathrm{KOH}(1.2 \\
\mathrm{gm}) \text { and } 3.78 \mathrm{~g} \\
\mathrm{Na}_{2} \mathrm{~S} \text { with pH } 5.9\end{array}$ & $300 \mathrm{mg}$ & $\begin{array}{l}500 \mathrm{~W} \text { xenon } \\
\text { lamp }\end{array}$ & methanol & $\sim 40 \mu \mathrm{molg}^{-1} \mathrm{~h}^{-1}$ & 69 \\
\hline
\end{tabular}


Table VIII. Performance of $\mathrm{Cu}$ (II)-based ternary oxides in dye degradation.

\begin{tabular}{|c|c|c|c|c|c|c|c|c|c|c|}
\hline No. & Oxide & Dye $^{a}$ & $\begin{array}{l}\text { Dye } \\
\text { concentration } \\
(\mathrm{mg} / \mathrm{L})\end{array}$ & $\begin{array}{l}\text { Catalyst } \\
\text { loading }(\mathrm{g} / \mathrm{L})\end{array}$ & $\begin{array}{l}\text { Solution } \\
\text { volume (ml) }\end{array}$ & $\begin{array}{l}\text { Irradiation } \\
\text { time (min) }\end{array}$ & $\begin{array}{l}\text { Irradiation } \\
\text { source }\end{array}$ & $\begin{array}{l}\text { Degradation } \\
(\%)\end{array}$ & Comments & Ref. \\
\hline 1 & $\mathrm{CuAl}_{2} \mathrm{O}_{4}$ & MO & 10 & 3.0 & 50 & 120 & 125 W Hg lamp & 98 & - & 43 \\
\hline 3 & $\mathrm{CuCo}_{2} \mathrm{O}_{4}$ & MO & 10 & 0.6 & 50 & 180 & $\begin{array}{l}150 \mathrm{~W} \text { Xe arc } \\
\text { lamp }\end{array}$ & 42 & $\begin{array}{l}\text { With added } \\
0.5 \mathrm{~mL} \text { of } \\
\mathrm{H}_{2} \mathrm{O}_{2}(30 \\
\text { masst } \%)\end{array}$ & 59 \\
\hline 4 & $\mathrm{CuCr}_{2} \mathrm{O}_{4}$ & MB & 20 & 0.4 & 50 & 60 & $\begin{array}{l}250 \mathrm{~W} \\
\text { tungsten- } \\
\text { halogen } \\
\text { lamp }\end{array}$ & 98 & $\begin{array}{l}\text { With added } 50 \\
\mu \mathrm{L} \mathrm{H}_{2} \mathrm{O}_{2} \\
(30 \%)\end{array}$ & 61 \\
\hline 5 & $\mathrm{CuMoO}_{4}$ & MO & 10 & 2.0 & 50 & 60 & $\begin{array}{l}400 \mathrm{~W} \text { mercury } \\
\text { lamp }\end{array}$ & 72 & - & 72 \\
\hline 6 & $\beta-\mathrm{Cu}_{3} \mathrm{~V}_{2} \mathrm{O}_{8}$ & MO & 20 & 1.0 & 150 & 120 & $\begin{array}{l}150-\mathrm{W} \text { Xe arc } \\
\text { lamp }\end{array}$ & 78 & - & 81 \\
\hline 7 & $\gamma-\mathrm{Cu}_{3} \mathrm{~V}_{2} \mathrm{O}_{8}$ & MO & 10 & 3.0 & 50 & 100 & $\begin{array}{l}20 \mathrm{~W} \text { Xe arc } \\
\text { lamp }\end{array}$ & 73 & - & 80 \\
\hline 8 & $\mathrm{CuWO}_{4}$ & MB & 10 & 0.4 & 100 & 60 & $\begin{array}{l}\text { Xe arc lamp } \\
\left(20 \mathrm{mWcm}^{-2}\right)\end{array}$ & 100 & $\begin{array}{l}\text { With added } \\
1 \mathrm{mmol} \mathrm{H}_{2} \mathrm{O}_{2}\end{array}$ & 93 \\
\hline
\end{tabular}

${ }^{\mathrm{a}} \mathrm{MO}=$ methyl orange $\mathrm{MB}=$ methylene blue.

of the various $\mathrm{Cu}$-containing ternary oxides on a common energy scale. This is shown in Figure 13; a few of these cases for the $\mathrm{Cu}(\mathrm{I})$ compounds were considered by previous authors in their review article. $^{6}$ The compilation in Figure 13 is more extensive; 24 compounds are compared here along with the two parent oxides, $\mathrm{Cu}_{2} \mathrm{O}$ and $\mathrm{CuO}$.

The thermodynamic utility of diagrams such as those in Figure 13 resides with the fact that predictions may be made for a given compound's ability to oxidize (or reduce) a targeted solution species such as water, protons, or $\mathrm{CO}_{2}$. Since the band edges move with solution $\mathrm{pH}$, it is judicious to do comparative assessments at a common $\mathrm{pH}, \mathrm{pH}=0$ in this case.

\section{Quaternary Oxides Based on Copper}

These contain two other metal cations (B and $\mathrm{C}$ ) besides copper in the oxide structure. One such compound, $\mathrm{Cu}_{2} \mathrm{BiVO}_{6}$, was already considered in Figure 2b earlier and consists of a 4:1:1 combination of $\mathrm{Cu}_{2} \mathrm{O}, \mathrm{Bi}_{2} \mathrm{O}_{3}$ and $\mathrm{V}_{2} \mathrm{O}_{5}$. Unlike the literature on ternary counterparts, instances where quaternary $\mathrm{Cu}$-based oxides have been studied, are very sparse. This trend also contrasts with the rather rich literature on Ag-based compounds. Thus, four specific compounds appear to have been studied in the copper case: $\mathrm{CuAlGaO}_{4},{ }^{111} \mathrm{Cu}_{2} \mathrm{BiVO}_{6}$ (c.f., Figure 2), ${ }^{112-114}$ and $\mathrm{CuBiW}_{2} \mathrm{O}_{8}{ }^{115}$ The first compound is a $2: 1: 1$ combination of $\mathrm{CuO}, \mathrm{Al}_{2} \mathrm{O}_{3}$, and $\mathrm{Ga}_{2} \mathrm{O}_{3}$, while the third is a $1: 1: 4$ combination of $\mathrm{Cu}_{2} \mathrm{O}, \mathrm{Bi}_{2} \mathrm{O}_{3}$, and $\mathrm{WO}_{3}$. These have been prepared by a diverse range of methods including solid-state synthesis, ${ }^{111}$ chemical solution, ${ }^{113}$ and the use of a polymeric citrate complex precursor. ${ }^{12}$ The compounds also have been evaluated for their propensity to evolve $\mathrm{H}_{2}$ (from $\left.\mathrm{H}_{2} \mathrm{~S}\right),{ }^{11} \mathrm{O}_{2}{ }^{114}$ or decompose a dye (e.g., rhodamine $\left.\mathrm{B}\right)^{112}$ under visible light irradiation. Clearly, studies on quaternary $\mathrm{Cu}$-based oxides remain a fertile field of opportunity for further studies.

\section{Concluding Remarks}

Any research endeavor may be evaluated on the basis of two yard sticks: a) has it pushed the knowledge boundary forward in a transformative sense? And b) has it spawned a new technology? Recall also that the extension of the search for optimal inorganic semiconductors into the ternary (or higher) compound domain, was largely spurred by the perceived handicaps associated with the binary oxide counterparts. In the present instance, the lack of adequate photoelectrochemical stability of $\mathrm{Cu}_{2} \mathrm{O}$ was the major driver for the search for ternary copper-based semiconductors. Are the ternary compounds more stable in a photoelectrochemical sense? The jury is still out on this aspect although there are encouraging signs that insertion of the $B$ cation (in to the copper oxide framework) can perturb the parent electronic band structure sufficiently to stabilize the compound against photocorrosion.

Returning to the two questions posed earlier, this review demonstrates that major strides have been made in the fundamental understanding of ternary oxide semiconductors. That being said, much more must be accomplished in selected areas, and identified in the preceding sections of this article. In a practical sense, more optimization has to be done in aspects related to materials quality etc., before performance levels (e.g., photocurrents in the $10-20 \mathrm{~mA} / \mathrm{cm}^{2}$ ) can be achieved in a PEC environment (c.f., Tables IV; the maximum observed to date is $2.5 \mathrm{~mA} / \mathrm{cm}^{2}$, entry \#1). Only then will the engineering community be motivated to tackle aspects related to photoreactor design, scale-up etc., and a viable technology emerge from all the science that would have been done up to that juncture.

Admittedly, this review has given short shrift to how theory can contribute to materials discovery, properties, and use. This reflects the authors' bias, more than anything else. Clearly, methods such as DFT (in spite of their well-recognized handicaps) and as briefly alluded to above, continue to provide much guidance to experimentalists in terms of understanding electronic band structures and their dependence on chemical composition. Although much more nascent, phase field models ${ }^{116}$ can map morphological effects on materials properties on a mesoscale level. Such theoretical efforts could provide crucial support to the experimentalists in the continuing search and optimization of oxide semiconductors (such as the $\mathrm{Cu}$-based compounds considered in this review) for solar fuels photogeneration and environmental remediation applications.

\section{Acknowledgments}

K.R., R.T.M. and M.K.H. thank the University of Texas at Arlington for partial support of this research project. C.J. thanks the European Research Council (ERC) under the European Union's Horizon 2020 


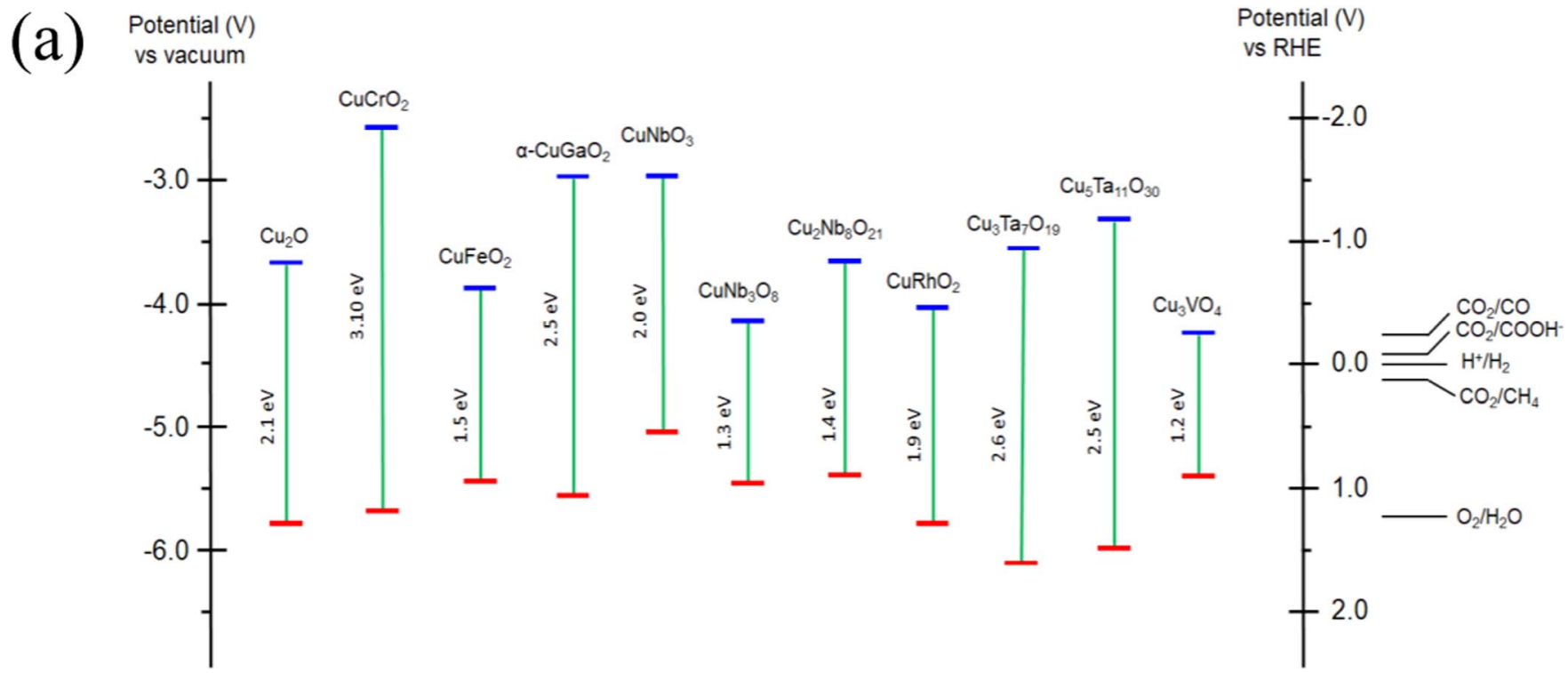

(b)

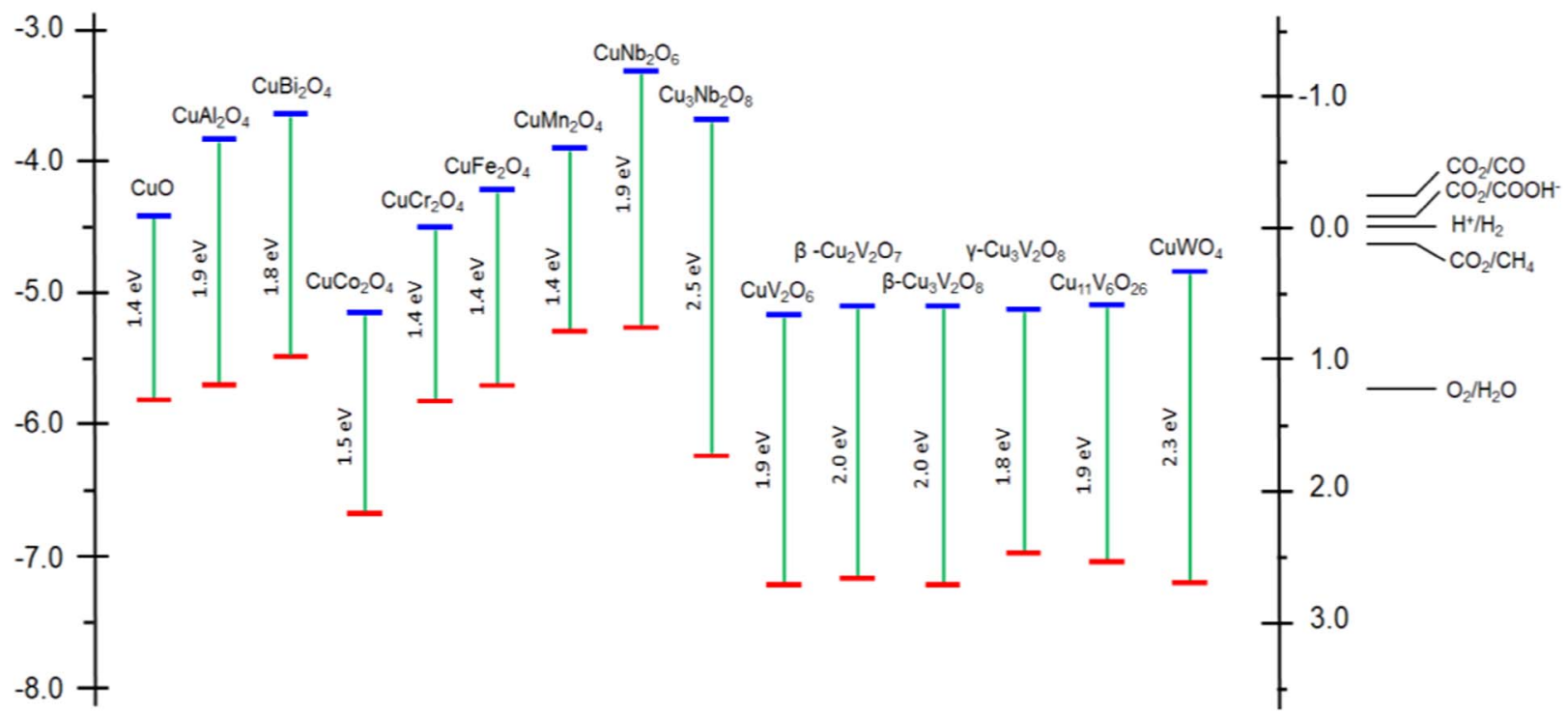

Figure 13. Band edge positions for $\mathrm{Cu}(\mathrm{I})$ (a) and $\mathrm{Cu}(\mathrm{II})$ (b) ternary oxides. Data on the parent binary oxides and relevant redox potentials are also shown for comparison.

research and innovation program (grant Agreement No. 716539), and the "Széchenyi 2020" program in the framework of GINOP-2.3.2-152016-00013. P.J.K. appreciates support by the National Science Center (Poland) under Maestro Project 2012/04/A/ST4/00287. Finally, we appreciate the constructive criticisms of two anonymous reviewers on an earlier version of this manuscript.

\section{ORCID}

Krishnan Rajeshwar (D https://orcid.org/0000-0003-4917-7790

\section{References}

1. A. Hamnett, M. P. Dare-Edwards, R. D. Wright, K. R. Seddon, and J. B. Goodenough, "Photosensitization of titanium(IV) oxide with tris(2,2'- bipyridine) ruthenium(II) chloride. Surface states of titanium(IV) oxide." J. Phys. Chem., 83, 3280 (1979).

2. S. Anderson, E. C. Constable, M. P. Dare-Edwards, J. B. Goodenough, A. Hamnett, K. R. Seddon, and R. D. Wright, "Chemical modification of a titanium (IV) oxide electrode to give stable dye sensitisation without a supersensitiser." Nature, 280, 571 (1979).

3. H. H. Kung, H. S. Jarrett, A. W. Sleight, and A. Ferretti, "Semiconducting oxide anodes in photoassisted electrolysis of water." J. Appl. Phys., 48, 2463 (1977).

4. J. Baglio, E. Kamieniecki, N. DeCola, C. Struck, J. Marzik, K. Dwight, and A. Wold, "Growth and characterization of $\mathrm{n}-\mathrm{WS}_{2}$ and niobium-doped $\mathrm{p}-\mathrm{WS}_{2}$ single crystals." J. Solid State Chem., 49, 166 (1983).

5. J. Gu, A. Wuttig, J. W. Krizan, Y. Hu, Z. M. Detweiler, R. J. Cava, and A. B. Bocarsly, "Mg-doped $\mathrm{CuFeO}_{2}$ photocathodes for photoelectrochemical reduction of carbon dioxide." J. Phys. Chem., 117, 12415 (2013).

6. U. A. Joshi, A. Palasyuk, D. Arney, and P. A. Maggard, "Semiconducting oxides to facilitate the conversion of solar energy to chemical fuels." J. Phys. Chem. Lett., 1, 2719 (2010).

7. Y. Mao, T-J. Park, and S. S. Wong, "Synthesis of classes of ternary metal oxide nanostructures," ChemComm, 5721 (2005). 
8. D. Chen, Q. Wang, R. Wang, and G. Shen, "Ternary oxide nanostructured materials for supercapacitors: a review." J. Mater. Chem. A, 3, 10158 (2015).

9. W. G. Zeir, A. Zevalkink, Z. M. Gibbs, G. Hautier, M. G. Kanatzidis, and G. J. Snyder, "Thinking like a chemist: intuition in thermoelectric materials." Angew. Chem. Int. Ed., 55, 6826 (2016)

10. G. Hautier, S. P. Ong, A. Jain, C. J. Moore, and G. Ceder, "Accuracy of density functional theory in predicting formation energies of ternary oxides from binary oxides and its implication on phase stability." Phys. Rev. B, 85, 155208 (2012).

11. T. F. T. Cerqueira, S. Lin, M. Amsler, S. Goedecker, S. Botti, and M. A. L. Marques, "Identification of novel $\mathrm{Cu}, \mathrm{Ag}$, and $\mathrm{Au}$ ternary oxides from global structural prediction." Chem. Mater. 27, 4562 (2015).

12. J. R. Smith, T. H. Van Steenkiste, and X. G. Wang, "Thermal photocatalytic generation of $\mathrm{H}_{2}$ over $\mathrm{CuAlO}_{2}$ nanoparticle catalysts in $\mathrm{H}_{2} \mathrm{O}$." Phys. Rev. B, 79, 041403-1-4 (2009).

13. J. R. Ahmed, C. K. Blakely, J. Prakash, S. R. Bruno, M. Yu, Y. Wu, and V. V. Poltavets, "Scalable synthesis of delafossite $\mathrm{CuAlO}_{2}$ nanoparticles for p-type dye-sensitized solar cells applications." J. Alloys Compd., 591, 275 (2014).

14. N. Koriche, A. Bouguelia, A. Aider, and M. Trari, "Photocatalytic hydrogen evolution over delafossite $\mathrm{CuAlO}_{2}$." Int. J. Hydrog. Energy, 30, 693 (2005).

15. A. Nattestad, X. Zhang, U. Bach, and Y-B. Cheng, "Dye-sensitized $\mathrm{CuAlO}_{2}$ photocathodes for tandem solar cell applications." J. Photonics Energy, 1, 011103-1-9 (2011).

16. C. Creissen, J. Warnan, and E. Reisner, "Solar $\mathrm{H}_{2}$ generation in water with a $\mathrm{CuCrO}_{2}$ photocathode modified with an organic dye and molecular Ni catalyst." Chem. Sci, (2018).

17. S. Saadi, A. Bouguelia, and M. Trari, "Photocatalytic hydrogen evolution over $\mathrm{CuCrO}_{2} . "$ Solar Energy, 80, 272 (2006).

18. C. G. Read, Y. Park, and K. S. Choi, "Electrochemical synthesis of p-type $\mathrm{CuFeO}_{2}$ electrodes for use in a photoelectrochemical cell." J. Phys. Chem. Lett., 3, 1872 (2012).

19. M. S. Prévot, N. Guijarro, and K. Sivula, "Enhancing the performance of a robust sol-gel processed p-type delafossite $\mathrm{CuFeO}_{2}$ photocathode for solar water reduction". ChemSusChem, 8, 1359 (2015).

20. Y. J. Jang, Y. B. Park, H. E. Kim, Y. H. Choi, S. H. Choi, and J. S. Lee, "Oxygenintercalated $\mathrm{CuFeO}_{2}$ photocathode fabricated by hybrid microwave annealing for efficient solar hydrogen production." Chem. Mater, 28, 6054 (2016).

21. M. S. Prévot, A. X. Jeanbourquin, W. S. Bourée, F. Abdi, Friedrich D, R. Van Dr Krol, N. Guijarro, F. Le Formal, and K. Sivula, "Evaluating charge carrier transport and surface states in $\mathrm{CuFeO}_{2}$ photocathodes." Chem. Mater, 29, 4952 (2017).

22. J. W. Lekse, M. K. Underwood, J. P. Lewis, and C. Matranga, "Synthesis, characterization, electronic structure, and photocatalytic behavior of $\mathrm{CuGaO}_{2}$ and $\mathrm{CuGa}_{-\mathrm{x}} \mathrm{Fe}_{\mathrm{x}} \mathrm{O}_{2}(\mathrm{x}=0.05,0.10,0.15,0.20)$ delafossites." J. Phys. Chem. C, 116, 1865 (2012)

23. M. Yu, G. Natu, Z. Ji, and Y. Wu, "P-type dye-sensitized solar cells based on delafossite $\mathrm{CuGaO}_{2}$ nanoplates with saturation photovoltages exceeding $460 \mathrm{mV}$." J. Phys. Chem. Lett., 3, 1074 (2012).

24. A. Renaud, B. Chavillon, L. Le Pleux, Y. Pellegrin, E. Blart, M. Boujtita, T. Pauporté, L. Cario, S. Jobic, and F. Odobele, " $\mathrm{CuGaO}_{2}$ : a promising alternative for $\mathrm{NiO}$ in p-type dye solar cells." J. Mater. Chem, 22, 14353 (2012).

25. K. Gurunathan, J. Baeg, S. M. Lee, E. Subramanian, S. Moon, and K. Kong, "Visible light assisted highly efficient hydrogen production from $\mathrm{H}_{2} \mathrm{~S}$ decomposition by $\mathrm{CuGaO}_{2}$ and $\mathrm{CuGa}_{1-x} \mathrm{In}_{\mathrm{x}} \mathrm{O}_{2}$ delafossite oxides bearing nanostructured co-catalysts." Cat. Comm., 9, 395 (2008)

26. H. Kumagai, G. Sahara, K. Maeda, M. Higashi, R. Abe, and O. Ishitani, "Hybrid photocathode consisting of a $\mathrm{CuGaO}_{2}$ p-type semiconductor and a $\mathrm{Ru}$ (II)-Re (I) supramolecular photocatalyst: non-biased visible-light-driven $\mathrm{CO}_{2}$ reduction with water oxidation." Chem. Sci, 8, 4242 (2017).

27. T. Omata, H. Nagatani, I. Suzuki, M. Kita, H. Yanagi, and N. Ohashi, "Wurtzite $\mathrm{CuGaO}_{2}$ : a new direct and narrow bandgap oxide semiconductor applicable as a solar cell absorber." J. Am. Chem. Soc., 136, 3378 (2014).

28. H. Nagatani, I. Suzuki, M. Kita, M. Tanaka, Y. Katsuya, O. Sakata, S. Miyoshi, S. Yamaguchi, and T. Omata, "Structural and thermal properties of ternary narrowgap oxide semiconductor; wurtzite-derived $\beta-\mathrm{CuGaO}_{2}$." Inorg. Chem., 54, 1698 (2015).

29. U. A. Joshi, A. Palasyuk, and P. A. Maggard, "Photoelectrochemical investigation and electronic structure of a p-type $\mathrm{CuNbO}_{3}$ photocathode." J. Phys. Chem. C, $\mathbf{1 1 5}$ 13534 (2011)

30. B. Zoellner, S. Stuart, C. Chung, D. B. Dougherty, J. L. Jones, and P. A. Maggard, "CuNbTaO $(\mathrm{x} \leq 0.25)$ solid solutions: impact of $\mathrm{Ta}(\mathrm{v})$ substitution and $\mathrm{Cu}(\mathrm{I})$ deficiency on their structure, photocatalytic, and photoelectrochemical properties." J. Mater. Chem. A, 4, 3115 (2016)

31. U. A. Joshi and P. A. Maggard, " $\mathrm{CuNb}_{3} \mathrm{O}_{8}$ : a p-type semiconducting metal oxide photoelectrode." J. Phys. Chem. Lett., 3, 1577 (2012).

32. N. King, P. P. Sahoo, L. Fuoco, S. Stuart, D. Dougherty, Y. Liu, and P. A. Maggard, "Copper deficiency in the p-type semiconductor $\mathrm{Cu}_{1-\mathrm{x}} \mathrm{Nb}_{3} \mathrm{O}_{8}$." Chem. Mater, 26 , 2095 (2014)

33. J. Choi, N. King, and P. A. Maggard, "Metastable Cu (I)-niobate semiconductor with a low-temperature, nanoparticle-mediated synthesis." ACS Nano, 7, 1699 (2013).

34. J. Gu, Y. Yan, J. W. Krizan, Q. D. Gibson, Z. M. Detweiler, R. J. Cava, and A. B. Bocarsly, "P-type $\mathrm{CuRhO}_{2}$ as a self-healing photoelectrode for water reduction under visible light." J. Am. Chem. Soc., 136, 830 (2014).

35. N. King, I. Sullivan, P. Watkins-Curry, J. Y. Chan, and P. A. Maggard, "Fluxmediated syntheses, structural characterization and low-temperature polymor- phism of the p-type semiconductor $\mathrm{Cu}_{2} \mathrm{Ta}_{4} \mathrm{O}_{11}$."J. Solid State Chem., 236, 10 (2016)

36. N. King, R. D. Sommer, P. Watkins-Curry, J. Y. Chan, and P. A. Maggard, "Synthesis, structure, and thermal instability of the $\mathrm{Cu}_{2} \mathrm{Ta}_{4} \mathrm{O}_{11}$ phase." Cryst. Growth Des., $15,552(2015)$

37. L. Fuoco, U. A. Joshi, and P. A. Maggard, "Preparation and photoelectrochemical properties of p-type $\mathrm{Cu}_{5} \mathrm{Ta}_{11} \mathrm{O}_{30}$ and $\mathrm{Cu}_{3} \mathrm{Ta}_{7} \mathrm{O}_{19}$ semiconducting polycrystalline films." J. Phys. Chem. C, 116, 10490 (2012).

38. H. Kato, A. Takeda, M. Kobayashi, M. Hara, and M. Kakihana, "Photocatalytic activities of $\mathrm{Cu}_{3 x} \mathrm{La}_{1-x} \mathrm{Ta}_{7} \mathrm{O}_{19}$ solid solutions for $\mathrm{H}_{2}$ evolution under visible light irradiation." Catal. Sci. Technol., 3, 3147 (2013).

39. I. Sullivan, P. P. Sahoo, L. Fuoco, A. Hewitt, S. Stuart, D. Dougherty, and P. A. Maggard, "Cu-deficiency in the p-type semiconductor $\mathrm{Cu}_{5-\mathrm{x}} \mathrm{Ta}_{11} \mathrm{O}_{30}$ : impact on its crystalline structure, surfaces, and photoelectrochemical properties." Chem. Mater, 26, 6711 (2014)

40. P. P. Sahoo, B. Zoellner, and P. A. Maggard, "Optical, electronic, and photoelectrochemical properties of the p-type $\mathrm{Cu}_{3-} \mathrm{V} \mathrm{VO}_{4}$ semiconductor." J. Mater. Chem. A, 3, 4501 (2015)

41. J. Yanyan, L. Jinggang, S. Xiaotao, N. Guiling, W. Chengyu, and G. Xiumei, " $\mathrm{CuAl}_{2} \mathrm{O}_{4}$ powder synthesis by sol-gel method and its photodegradation property under visible light irradiation." J. Sol-Gel Sci. Technol, 42, 41 (2007).

42. S. A. Hassanzadeh-Tabrizi, R. Pournajaf, A. Moradi-Faradonbeh, and S. Sadeghinejad, "Nanostructured $\mathrm{CuAl}_{2} \mathrm{O}_{4}$ : co-precipitation synthesis, optical and photocatalytic properties." Ceram. Int. 42, 14121 (2016).

43. W. Lv, B. Liu, Q. Qiu, F. Wang, Z. Luo, P. Zhang, and S. Wei, "Synthesis, characterization and photocatalytic properties of spinel $\mathrm{CuAl}_{2} \mathrm{O}_{4}$ nanoparticles by a sonochemical method." J. Alloys Compd., 479, 480 (2009).

44. S. Saadi, A. Bouguelia, and M. Trari, "Photoassisted hydrogen evolution over spinel $\mathrm{CuM}_{2} \mathrm{O}_{4}(\mathrm{M}=\mathrm{Al}, \mathrm{Cr}, \mathrm{Mn}, \mathrm{Fe}$ and Co)." Renewable Energy, 31, 2245 (2006).

45. N. T. Hahn, V. C. Holmberg, B. A. Korgel, and C. B. Mullins, "Electrochemica synthesis and characterization of $\mathrm{p}-\mathrm{CuBi}_{2} \mathrm{O}_{4}$ thin film photocathodes." J. Phys. Chem. C, 116, 6459 (2012).

46. Y. Xie, Y. Zhang, G. Yang, C. Liu, and J. Wang, "Hydrothermal synthesis of $\mathrm{CuBi}_{2} \mathrm{O}_{4}$ nanosheets and their photocatalytic behavior under visible light irradiation." Mater Lett., 107, 291 (2013)

47. Y. Deng, Y. Chen, B. Chen, and J. Ma, "Preparation, characterization and photocatalytic activity of $\mathrm{CuBi}_{2} \mathrm{O}_{4} / \mathrm{NaTaO}_{3}$ coupled photocatalysts." Alloys Compd., 559 , 116 (2013)

48. R. Patil, S. Kelkar, R. Naphade, and S. Ogale, "Low temperature grown $\mathrm{CuBi}_{2} \mathrm{O}_{4}$ with flower morphology and its composite with $\mathrm{CuO}$ nanosheets for photoelectrochemical water splitting." J. Mater. Chem. A, 2, 3661 (2014).

49. Y. Nakabayashi, M. Nishikawa, and Y. Nosaka, "Fabrication of $\mathrm{CuBi}_{2} \mathrm{O}_{4}$ photocathode through novel anodic electrodeposition for solar hydrogen production." Electrochim. Acta, 125, 191 (2014)

50. M. Wang, J. Zai, X. Wei, W. Chen, N. Liang, M. Xu, R. Qi, and X. Qian, "N-type hedgehog-like $\mathrm{CuBi}_{2} \mathrm{O}_{4}$ hierarchical microspheres: room temperature synthesis and their photoelectrochemical properties." CrystEng Comm, 17, 4019 (2015).

51. G. Sharma, Z. Zhao, P. Sarker, B. A. Nail, J. Wang, M. N. Huda, and F. E. Osterloh, "Electronic structure, photovoltage, and photocatalytic hydrogen evolution with $\mathrm{p}$ $\mathrm{CuBi}_{2} \mathrm{O}_{4}$ nanocrystals." J. Mater. Chem. A, 4, 2936 (2016).

52. S. P. Berglund, F. F. Abdi, P. Bogdanoff, A. Chemseddine, D. Friedrich, and R. van de Krol, "Comprehensive evaluation of $\mathrm{CuBi}_{2} \mathrm{O}_{4}$ as a photocathode material for photoelectrochemical water splitting." Chem. Mater, 28, 4231 (2016).

53. D. Cao, N. Nasori, Z. Wang, Y. Mi, L. Wen, Y. Yang, S. Qu, Z. Wang, and Y. Lei, "p-type $\mathrm{CuBi}_{2} \mathrm{O}_{4}$ : an easily accessible photocathodic material for high-efficiency water splitting." J. Mater. Chem. A, 4, 8995 (2016).

54. D. Kang, J. C. Hill, Y. Park, and K. S. Choi, "Photoelectrochemical properties and photostabilities of high surface area $\mathrm{CuBi}_{2} \mathrm{O}_{4}$ and $\mathrm{Ag}$-Doped $\mathrm{CuBi}_{2} \mathrm{O}_{4}$ photocathodes." Chem. Mater, 28, 4331 (2016).

55. M. K. Hossain, G. F. Samu, K. Gandha, S. Santhanagopalan, J. P. Liu, C. Janáky, and K. Rajeshwar, "Solution combustion synthesis, characterization, and photocatalytic activity of $\mathrm{CuBi}_{2} \mathrm{O}_{4}$ and its nanocomposites with $\mathrm{CuO}$ and $\alpha ;-\mathrm{Bi}_{2} \mathrm{O}_{3}$." J. Phys. Chem. C, 121, 8252 (2017)

56. F. Wang, W. Septina, A. Chemseddine, F. Abdi, D. Friedrich, P. Bogdanoff, R. van de Krol, S. Tilley, and S. Berglund, "Gradient self-doped $\mathrm{CuBi}_{2} \mathrm{O}_{4}$ with highly improved charge separation efficiency.” J. Am. Chem. Soc., 139, 15094 (2017).

57. M. Jiang, Y. Gao, Z. Wang, and Z. Ding, "Photocatalytic $\mathrm{CO}_{2}$ reduction promoted by a $\mathrm{CuCo}_{2} \mathrm{O}_{4}$ co-catalyst with homogeneous and heterogeneous light harvesters." Appl. Catal. B Environ, 198, 180 (2016).

58. R. Rahmatolahzadeh, M. Mousavi-Kamazani, and S. Shobeiri, "Facile coprecipitation-calcination synthesis of $\mathrm{CuCo}_{2} \mathrm{O}_{4}$ nanostructures using novel precursors for degradation of azo dyes." J. Inorg. Organomet. Polym., 27, 313 (2016).

59. S. Jeghan, J. Do, and M. Kang, "Fabrication of flower-like copper cobaltite/graphiticcarbon nitride $\left(\mathrm{CuCO}_{2} \mathrm{O}_{4} / \mathrm{g}-\mathrm{C}_{3} \mathrm{~N}_{4}\right)$ composite with superior photocatalytic activity." Ind. Eng. Chem. Res., 57, 405 (2018).

60. S. Boumaza, R. Bouarab, Trari M, and A. Bouguelia, "Hydrogen photo-evolution over the spinel $\mathrm{CuCr}_{2} \mathrm{O}_{4}$." Energy Convers. Manag, 50, 62 (2009).

61. W. Yuan, X. Liu, and L. Li, "Synthesis, characterization and photocatalytic activity of cubic-like $\mathrm{CuCr}_{2} \mathrm{O}_{4}$ for dye degradation under visible light irradiation." Appl. Surf. Sci., 319, 350 (2014).

62. B. Paul, B. Bhuyan, D. D. Purkayastha, S. S. Dhar, and S. Behera, "Facile synthesis of spinel $\mathrm{CuCr}_{2} \mathrm{O}_{4}$ nanoparticles and studies of their photocatalytic activity in degradation of some selected organic dyes." J. Alloys Compd., 648, 629 (2015). 
63. K. Mageshwari, R. Sathyamoorthy, J. Y. Lee, and J. Park, "Novel $\mathrm{CuCr}_{2} \mathrm{O}_{4}$ embedded $\mathrm{CuO}$ nanocomposites for efficient photodegradation of organic dyes." Appl. Surf. Sci., 353, 95 (2015).

64. F. Beshkar, O. Amiri, M. Salavati-Niasari, and F. Beshkar, "Novel dendrite-like $\mathrm{CuCr}_{2} \mathrm{O}_{4}$ photocatalyst prepared by a simple route in order to remove of azo dye in textile and dyeing wastewater." J. Mater. Sci. Mater. Electron, 26, 8182 (2015).

65. L. Pan, L. Li, X. Bao, and Y. Chen, "Highly (sic) photocatalytic activity for pnitrophenol degradation with spinel-structured $\mathrm{CuCr}_{2} \mathrm{O}_{4}$." Micro Nano Lett, 7, 415 (2012).

66. H. Lahmara, M. Kebirb, N. Nasrallahb, and M. Trari, "Photocatalytic reduction of $\mathrm{Cr}(\mathrm{VI})$ on the new hetero-system $\mathrm{CuCr}_{2} \mathrm{O}_{4} / \mathrm{ZnO}$," J. Mol. Catal. A: Chem., 353, 74 (2012).

67. H. Yang, J. Yan, Z. Lu, X. Cheng, and Y. Tang, "Photocatalytic activity evaluation of tetragonal $\mathrm{CuFe}_{2} \mathrm{O}_{4}$ nanoparticles for the $\mathrm{H}_{2}$ evolution under visible light irradiation." J. Alloys Compd., 476, 715 (2009).

68. A. Kezzim, N. Nasrallah, A. Abdi, and M. Trari, "Visible light induced hydrogen on the novel hetero-system $\mathrm{CuFe}_{2} \mathrm{O}_{4} / \mathrm{TiO}_{2}$." Energy Convers. Manag, 52, 2800 (2011).

69. M. R. Uddin, M. R. Khan, M. W. Rahman, A. Yousuf, and C. K. Cheng, "Photocatalytic reduction of $\mathrm{CO}_{2}$ into methanol over $\mathrm{CuFe}_{2} \mathrm{O}_{4} / \mathrm{TiO}_{2}$ under visible light irradiation." React. Kinet. Mech. Cat., 116, 589 (2015).

70. K. Gurunathan, J. O. Baeg, S. M. Lee, E. Subramanian, S. J. Moon, and K. J. Kong, "Visible light active pristine and $\mathrm{Fe}^{3+}$ doped $\mathrm{CuGa}_{2} \mathrm{O}_{4}$ spinel photocatalysts for solar hydrogen production." Int. J. Hydrog. Energy, 33, 2646 (2008).

71. Y. Bessekhouad and M. Trari, "Photocatalytic hydrogen production from suspension of spinel powders $\mathrm{AMn}_{2} \mathrm{O}_{4}(\mathrm{~A}=\mathrm{Cu}$ and $\mathrm{Zn})$." Int. J. Hydrog. Energy, 27, 357 (2002).

72. M. Sadeghi, "Investigation of the structural, optical and magnetic properties of $\mathrm{CuMoO}_{4}$ nanoparticles synthesized through a sonochemical method." J. Mater. Sci. Mater. Electron, 27, 5796 (2016).

73. T. K. Ghorai, D. Dhak, S. Dalai, and P. Pramanik, "Effect of photocatalytic activities of nano-sized copper molybdate $\left(\mathrm{CuMoO}_{4}\right)$-doped bismuth titanate $\left(\mathrm{Bi}_{2} \mathrm{Ti}_{4} \mathrm{O}_{11}\right)(\mathrm{CMBT})$ alloy." Mater Res Bull., 43, 1770 (2008).

74. A. Kormányos, A. Thomas, M. N. Huda, P. Sarker, J. P. Liu, N. Poudyal, C. Janáky, and K. Rajeshwar, "Solution combustion synthesis, characterization, and photoelectrochemistry of $\mathrm{CuNb}_{2} \mathrm{O}_{6}$ and $\mathrm{ZnNb}_{2} \mathrm{O}_{6}$ nanoparticles." J. Phys. Chem. C, 120 16024 (2016).

75. S. Kamimura, N. Murakami, T. Tsubota, and T. Ohno, "Fabrication and characterization of a p-type $\mathrm{Cu}_{3} \mathrm{Nb}_{2} \mathrm{O}_{8}$ photocathode toward photoelectrochemical reduction of carbon dioxide." Appl. Catal. B Environ, 174, 471 (2015).

76. W. Guo, W. D. Chemelewski, Mabayoje O, P. Xiao, Y. Zhang, and C. B. Mullins, "Synthesis and characterization of $\mathrm{CuV}_{2} \mathrm{O}_{6}$ and $\mathrm{Cu}_{2} \mathrm{~V}_{2} \mathrm{O}_{7}$ : two photoanode candidates for photoelectrochemical water oxidation." J. Phys. Chem. C, 119, 27220 (2015).

77. P. F. Newhouse, D. A. Boyd, A. Shinde, D. Guevarra, L. Zhou, E. Soedarmadji, G. Li, J. B. Neaton, and J. M. Gregoire, "Solar fuel photoanodes prepared by inkje printing of copper vanadates." J. Mater. Chem. A, 4, 7483 (2016).

78. M. W. Kim, B. Joshi, H. Yoon, T. Y. Ohm, K. Kim, S. S. Al-Deyab, and S. S. Yoon, "Electrosprayed copper hexaoxodivanadate $\left(\mathrm{CuV}_{2} \mathrm{O}_{6}\right)$ and pyrovanadate $\left(\mathrm{Cu}_{2} \mathrm{~V}_{2} \mathrm{O}_{7}\right)$ photoanodes for efficient solar water splitting." J. Alloys Compd. 708, 444 (2017)

79. L. Zhou, Q. Yan, A. Shinde, D. Guevarra, P. F. Newhouse, N. Becerra-Stasiewicz, S. M. Chatman, J. A. Haber, J. B. Neaton, and J. M. Gregoire, "High throughput discovery of solar fuels photoanodes in the $\mathrm{CuO}-\mathrm{V}_{2} \mathrm{O}_{5}$ system." Adv. Energy Mater. 5, 1500968 (2015).

80. M. Wang and Q. Liu, "Synthesis and photocatalytic property of $\mathrm{Cu}_{3} \mathrm{~V}_{2} \mathrm{O}_{8}$ prepared by liquid phase precipitation." Adv Mat Res., 236, 1675 (2011).

81. S. Zhang, Y. Sun, C. Li, and L. Ci, " $\mathrm{Cu}_{3} \mathrm{~V}_{2} \mathrm{O}_{8}$ hollow spheres in photocatalysis and primary lithium batteries." Solid State Sci., 25, 15 (2013).

82. J. A. Seabold and N. R. Neale, "All first row transition metal oxide photoanode for water splitting based on $\mathrm{Cu}_{3} \mathrm{~V}_{2} \mathrm{O}_{8}$." Chem. Mater, 27, 1005 (2015).

83. D. Cardenas-Morcoso, A. Peiro-Franch, I. Herraiz-Cardona, and S. Gimenez, "Chromium doped copper vanadate photoanodes for water splitting." Cat. Today, 290, 65 (2017)

84. C. M. Jiang, M. Farmand, C. H. Wu, Y. S. Liu, J. Guo, W. S. Drisdell, J. K. Cooper, and I. D. Sharp, "Electronic structure, optoelectronic properties, and photoelectrochemical characteristics of $\gamma-\mathrm{Cu}_{3} \mathrm{~V}_{2} \mathrm{O}_{8}$ thin films." Chem. Mater., 29, 3334 (2017).

85. M. A. Lumley and K. S. Choi, "Investigation of pristine and (Mo, W)-Doped $\mathrm{Cu}_{11} \mathrm{~V}_{6} \mathrm{O}_{26}$ for use as photoanodes for solar water splitting." Chem. Mater, 29 9472 (2017)

86. F. A. Benko, C. L. Maclaurin, and F. P. Koffyberg, "CuWO ${ }_{4}$ and $\mathrm{Cu}_{3} \mathrm{WO}_{6}$ as anodes for the photoelectrolysis of water." Mater. Res. Bull., 17, 133-136 (1982).

87. J. P. Doumerc, J. Hejtmanek, J. P. Chaminade, M. Pouchard, and M. Krussanova, "A Photoelectrochemical study of $\mathrm{CuWO}_{4}$ single crystals." Phys. Stat. Sol., 82, 285-294 (1984)

88. J. E. Yourey, K. J. Pyper, J. B. Kurtz, and B. M. Bartlett, "Chemical stability of $\mathrm{CuWO}_{4}$ for photoelectrochemical water oxidation." J. Phys. Chem. C, 117, 8708-8718 (2013).

89. J. E. Yourey and B. M. Bartlett, "Electrochemical deposition and photoelectrochemistry of $\mathrm{CuWO}_{4}$, a promising photoanode for water oxidation." J. Mater. Chem., 21 $7651-7660(2011)$
90. Y. Chang, A. Braun, A. Deangelis, J. Kaneshiro, and N. Gaillard, "Effect of thermal treatment on the crystallographic, surface energetics, and photoelectrochemical properties of reactively co-sputtered copper tungstate for water splitting." J. Phys. Chem. C, 115, 25490-25495 (2011).

91. Y. Tang, N. Rong, F. Liu, M. Chu, H. Dong, Y. Zhang, and P. Xiao, "Enhancement of the photoelectrochemical performance of $\mathrm{CuWO}_{4}$ films for water splitting by hydrogen treatment." Appl. Surf. Sci., 361, 133-140 (2016).

92. Y. Gao, O. Zandi, and T. W. Hamann, "Atomic layer stack deposition-annealing synthesis of $\mathrm{CuWO}_{4}$." J. Mater. Chem. A, 4, 2826-2830 (2016).

93. X. Xie, M. Liu, C. Wang, L. Chen, J. Xu, Y. Cheng, H. Dong, F. Lu, W. H. Wang, $\mathrm{H} \mathrm{Liu}$, and W. Wang, "Efficient photo-degradation of dyes using $\mathrm{CuWO}_{4}$ nanoparticles with electron sacrificial agents: a combination of experimental and theoretical exploration." RSC Adv., 6, 953 (2016).

94. A. Thomas, C. Janáky, G. F. Samu, M. N. Huda, P. Sarker, J. P. Liu, V. Van Nguyen, E. H. Wang, K. A. Schug, and K. Rajeshwar, "Time and energy-efficient solution combustion synthesis of binary metal tungstate nanoparticles with enhanced photocatalytic activity." ChemSusChem., 8, 1652 (2015).

95. N. R. de Tacconi, H. K. Timmaji, W. Chanmanee, M. N. Huda, P. Sarker, C. Janaky, and K. Rajeshwar, "Photocatalytic generation of syngas using combustionsynthesized silver bismuth tungstate," ChemPhysChem., 13, 1 (2012).

96. J. K. Cooper, S. Gul, F. M. Toma, L. Chen, Y-S. Liu, J. Guo, J. W. Ager, J. Yano, and I. D. Sharp, "Indirect bandgap and optical properties of monoclinic bismuth vanadate," J. Phys. Chem. C, 119, 2969 (2015). See also references therein.

97. K. Watanabe, "Photocatalytic water splitting: Quantitative approaches toward photocatalyst by design," ACS Catal., 7, 8006 (2017).

98. A. Maegli, E. H. Otal, T. Hisatomi, S. Yoon, C. M. Leroy, N. Schauble, Y. Lu, M. Gratzel, and A. Weidenkaff, "Perovskite-type $\mathrm{LaTiO}_{2} \mathrm{~N}$ oxynitrides for solar water splitting: Influence of the synthesis conditions, "Energy Procedia 22, 61 (2012)

99. K. Sivula and R. van De Krol, "Semiconducting materials for photoelectrochemical energy conversion," Nat. Rev. Mater, 1, 1 (2016).

100. K. Rajeshwar, in Solar Hydrogen Generation: Toward a Renewable Energy Future, (edited by K. Rajeshwar, R. McConnell, and S. Licht,), Chapter 7, pp. 167, Kluwer Academic, New York (2008)

101. L. Vegard, "Die konstitution der mischkristalle und die raumfüllung der atome," Zeitschrift Für Phys., 5, 17.

102. G. M. Clark and R. Garlick, "Formation and properties of copper(I) divanadate(V)," J. Inorg. Nucl. Chem., 40, 1347 (1978). See also references therein.

103. N. S. Rao and O. G. Palanna, "Phase transitions in copper(II) orthovanadate," Bull. Mater. Sci., 16, 261 (1993).

104. D. Roy, G. F. Samu, M. K. Hossain, C. Janaky, and K. Rajeshwar, "On the measured optical bandgap values of inorganic oxide semiconductors for solar fuels generation," Catal. Today, 300, 136 (2018).

105. For example: H. Dong, G. Chen, J. Sun, C. Li, Y. Hu, and Z. Han, "Whole-visiblelight (sic) absorption of a mixed-valence silver vanadate semiconductor stemming from an assistant (sic) effect of d-d transition," Inorg. Chem., 54, 11826 (2015). See also references therein.

106. S. Hazra, S. Mandal, and A. Ghosh, "Transport mechanism in nonconventional bismuth cuprate glass," J. Chem. Phys., 104, 10041 (1996).

107. K. Rajeshwar, in Encyclopedia of Electrochemistry, (edited by S. Licht,), Chapter 1, pp. 3, Wiley-VCH, Weinheim (2001)

108. B. Endrodi, G. Bencsik, F. Darvas, R. Jones, K. Rajeshwar, and C. Janaky, "Continuous -flow electroreduction of carbon dioxide," Prog. Energy Combustion Sci. 62, 133 (2017)

109. E. Kecsenovity, B. Endrődi, Z. Pápa, K. Hernádi, K. Rajeshwar, and C. Janáky, "Decoration of ultralong carbon nanotubes with $\mathrm{Cu}_{2} \mathrm{O}$ nanocrystals: a hybrid platform for enhanced photoelectrochemical $\mathrm{CO}_{2}$ reduction," Journal of Materials Chemistry A, 4, 3139 (2016)

110. E. Kecsenovity, B. Endrődi, P. S. Tóth, Y. Zou, R. A. W. Dryfe, K. Rajeshwar, and C. Janáky, "Enhanced photoelectrochemical performance of cuprousoxide/graphene nanohybrids," Journal of the American Chemical Society, 139, 6682 (2017).

111. S. K. Biswas, J-O. Baeg, B. B. Kale, R. K. Yadav, S-J. Moon, K-J. Kong, and W-W. Soo, "An efficient visible-light active photocatalyst $\mathrm{CuAlGaO}$ for solar hydrogen production," Catal. Commun., 12, 651 (2011).

112. Z. Ding, Y. Fu, Z. Xie, and Z. Li, "A polymeric complex method to nanocrystalline $\mathrm{BiCu}_{2} \mathrm{VO}_{6}$ with visible light photocatalytic activity," Mater. Lett., 65, 460 (2011).

113. Y. Nakabayashi, M. Nishikawa, and Y. Nosaka, "Fabrication of bismuth copper vanadate electrodes through feasible chemical solution method for visible lightinduced water oxidation," J. Appl. Electrochem., 46, 9 (2015).

114. H. Liu, R. Nakamura, and Y. Nakato, "Bismuth-copper vanadate $\mathrm{BiCu}_{2} \mathrm{VO}_{6}$ as a novel photocatalyst for efficient visible light driven oxygen evolution," ChemPhysChem., 6, 2499 (2005)

115. P. Sarker, D. Prasher, N. Gaillard, and M. N. Huda, "Predicting a new photocatalyst and its electronic properties by density functional theory," J. Appl. Phys., 114, 133508 (2013).

116. For example, Y. Cao, J. Shen, C. Randall, and L-Q. Chen, "Effect of multi-domain structure on ionic transport, electrostatics, and current evolution in $\mathrm{BaTiO}_{3}$ ferroelectric capacitor," Acta Mater., 112, 224 (2016). See also references therein. 